WILLIANS DE OLIVEIRA SANTOS

Produção de poli-3-hidroxibutirato em Escherichia coli recombinante com deleção dos genes que codificam as enzimas com atividade transidrogenase

São Paulo 2019 
WILLIANS DE OLIVEIRA SANTOS

\section{Produção de poli-3-hidroxibutirato em Escherichia coli recombinante com deleção dos genes que codificam as enzimas com atividade transidrogenase}

Dissertação apresentada à Escola Politécnica da Universidade de São Paulo como parte dos requisitos para obtenção do Título de Mestre em Ciências pelo programa de pós-graduação em Engenharia Química.

Área de Concentração: Engenharia Química

Orientador: Prof. Dr. Thiago Olitta Basso

Co-orientador: Prof. Dr. José Gregório Cabrera Gomez

São Paulo 
Dissertação de autoria de Willians de Oliveira Santos, sob o título "Produção de poli-3-hidroxibutirato em Escherichia coli recombinante com deleção dos genes que codificam as enzimas com atividade transidrogenase", apresentada à Escola Politécnica da Universidade de São Paulo, para obtenção do título de Mestre em Ciências pelo Programa de Pós-graduação em Engenharia Química, aprovada em de de pela comissão julgadora constituída pelos doutores:

Prof. Dr. Instituição:

Presidente

Prof. Dr. Instituição:

Prof. Dr. Instituição:

Prof. Dr. Instituição: 


\section{Agradecimentos}

Ao professor Doutor Thiago Olitta Basso, por ser meu orientador neste trabalho, por todo auxílio na parte experimental desde apresentar as instalações e equipamentos do laboratório, a como realizar todos os procedimentos de forma correta e a contribuir também para o planejamento dos experimentos, ao professor Doutor José Gregório Cabrera Gomez, por ser meu co-orientador, por me fornecer material preliminar de estudo e os trabalhos anteriores feitos neste assunto, por me permitir acompanhar os experimentos de seus alunos, por fornecer as cepas utilizadas neste trabalho, e por toda contribuição no planejamento dos experimentos, e ao professor Doutor Galo Antonio Carrilo Le Roux, por me ajudar no desenvolvimento do projeto, por me guiar na pesquisa literária e na construção do texto, por sanar minhas dúvidas e por indicar pessoas que também me ajudariam na realização deste trabalho

Ao Conselho Nacional de Desenvolvimento Científico e Tecnológico, CNPq, por me conceder a bolsa de mestrado, permitindo assim que eu me concentrasse nas atividades da pesquisa durante todo este tempo de mestrado.

Aos Doutores, Mestres e alunos de IC, Bruno Labate, Dielle Pierotti, Thiago Araújo, Priscila Jesus, Gabriel Caetano, Jessica Rubira, Matheus Guedes, Andreia Carneiro, Rafael David, Priscila Paz, Rosmary Rebaza, Mariana Kanbe, Jefferson Gonçalves, Sofía López, Pedro Henrique, Amanda Flora e Vânia Novello, por toda a ajuda e auxílio nos experimentos em biorreator, seja com a montagem e preparação, com a operação do biorreator durante o tempo de ensaio, e com os procedimentos de limpeza e descontaminação ao final dos experimentos.

Aos meus familiares por todo o apoio e pelo entendimento de que a área de pesquisa acadêmica é meu maior interesse, e que mesmo que não seja tão imediatamente recompensadora como trabalhar na indústria, irá me permitir colher muitos frutos no futuro, e a todos os meus amigos que me incentivaram no estudo e na busca por conhecimento, e por acreditarem que eu sou capaz de seguir o campo de pesquisa científica. 
"O degrau da escada não foi inventado para repousar, mas apenas para sustentar o pé o tempo necessário para que o homem coloque o outro pé um pouco mais alto." (Aldous Huxley) 


\section{Resumo}

SANTOS, Willians de Oliveira. Produção de poli-3-hidroxibutirato em Escherichia coli recombinante, com deleção dos genes que codificam as enzimas com atividade transidrogenase. 2019. 73 f. Dissertação (Mestre em Ciências) - Escola Politécnica, Universidade de São Paulo, São Paulo, 2019.

O uso de materiais plásticos tem sido proeminente na sociedade moderna dada sua versatilidade de aplicações, mas acarreta um grande problema, o processo de descarte. Plásticos convencionais são derivados do petróleo que levam anos para degradar na natureza, causando sérios problemas ambientais. Neste cenário, o desenvolvimento de bioplásticos que utilizam fontes renováveis como matéria prima e são biodegradáveis, é uma possível solução. Contudo, bioplásticos como o poli-3hidroxibutirato (P3HB), são mais caros que os plásticos convencionais. Em vista disso, muitos estudos atuais têm como foco melhorar a viabilidade econômica da produção de bioplásticos. Este trabalho teve como objetivo testar cepas mutantes de Escherichia coli recombinante, com deleção nos genes que codificam as enzimas com ação transidrogenase, com o intuito de avaliar a produção de P3HB. Três cepas, o tipo selvagem, uma mutante com deleção do operon pntAB e uma com deleção do gene udhA foram cultivadas em experimentos em frasco e em biorreator, em condições de oxigênio limitado. Os experimentos em frasco agitado apontaram que a cepa $\triangle p n t A B$ teve o maior fator de conversão dentre as três cepas, no meio mineral sem suplementação de $\mathrm{NaCl}(0,228 \mathrm{~g} \mathrm{P} 3 \mathrm{HB} / \mathrm{g}$ glicose). No entanto, a cepa selvagem foi a que alcançou a maior produtividade $(0,0184 \mathrm{~g} \mathrm{P} 3 \mathrm{HB} / \mathrm{L}$.h) no meio suplementado com $\mathrm{NaCl}$. Nos biorreatores, a cepa selvagem foi a que obteve a maior velocidade específica de crescimento, fator de conversão e produtividade, com $0,69 \mathrm{~h}^{-1}, 0,0063 \mathrm{~g} \mathrm{P} 3 \mathrm{HB} / \mathrm{g}$ glicose e 0,0043 g P3HB/L.h, respectivamente. Estes resultados indicam que a deleção do operon pntAB foi positiva para a produção de P3HB em frasco agitado, especialmente em meio sem suplementação de $\mathrm{NaCl}$. Em contrapartida, a deleção do operon pntAB ou do gene udhA não foi benéfica nos cultivos em biorreator com suplementação de $\mathrm{NaCl}$, onde foi notado também, acúmulo de lactato, para as cepas com deleção.

Palavras-chave: P3HB, E. coli recombinante, Transidrogenases, NADPH. 


\begin{abstract}
SANTOS, Willians de Oliveira. Production of poly-3-hydroxybutyrate in recombinant Escherichia coli, with deletion of the genes encoding the transhydrogenase enzymes. 2019. 73 p. Dissertation (Master of Science) Polytechnic School, University of São Paulo, São Paulo, 2019.
\end{abstract}

The use of plastic materials has been prominent in modern society given its versatility of applications, but it faces a major problem: the disposal process. Conventional plastics are oil-derived products that take several years to degrade in nature and cause serious environmental problems. In this scenario, the development of bioplastics that use renewable sources as feedstock and are biodegradable, is a potential solution to this problem. However, bioplastics such as the poly-3hydroxybutyrate $(\mathrm{P} 3 \mathrm{HB})$, are more expensive than conventional plastics. Current efforts have been focused on improving the cost-effectiveness of bioplastic production. This work aimed to test strains of recombinant Escherichia coli, with deletion on the transhydrogenase genes, in order to evaluate the production of P3HB. Three strains, the wild type, a mutant with a deletion of the operon pntAB and another mutant with a deletion of the gene $u d h A$, were cultivated in shake flasks and in bioreactors, in oxygen-limited condition. Shake flask experiments pointed that strain $\triangle p n t A B$ had the highest $\mathrm{P} 3 \mathrm{HB}$ yield on glucose among the strains, on mineral medium without supplementation of $\mathrm{NaCl}(0.228 \mathrm{~g} \mathrm{P} 3 \mathrm{HB} / \mathrm{g}$ glucose). However, the wild type strain reached the highest productivity $(0.0184 \mathrm{~g} \mathrm{P} 3 \mathrm{HB} / \mathrm{L} . \mathrm{h})$ in medium supplemented with $\mathrm{NaCl}$. In bioreactors, the wild type strain reached the highest specific growth rate, yield and $\mathrm{P} 3 \mathrm{HB}$ productivity, with $0.69 \mathrm{~h}^{-1}, 0.0063 \mathrm{~g} \mathrm{P} 3 \mathrm{HB} / \mathrm{g}$ glucose and $0.0043 \mathrm{~g} \mathrm{P} 3 \mathrm{HB} / \mathrm{L}$.h, respectively. These results indicated that deletion of the pntAB operon was effective for P3HB production in shake flask cultures, especially in media without $\mathrm{NaCl}$ supplementation. On the other hand, deletion of the pntAB operon or the $u d h A$ gene was not effective in bioreactor cultivations using medium supplemented with $\mathrm{NaCl}$, where accumulation of lactate was noticed for the two deleted strains.

Keywords: $\mathrm{P} 3 \mathrm{HB}$, recombinant E. coli, Transhydrogenases, NADPH. 


\section{Lista de figuras}

Figura 1 - Acúmulo de lixo plástico em aterro sanitário

Figura 2 - Degradação de um filme de polihidroxialcanoato (PHA) em

aproximadamente 50 dias .

Figura 3 - Ciclo do carbono de PHAs 13

Figura 4 - Estrutura geral dos polihidroxialcanoatos

Figura 5 - Grânulos de PHAs acumulados em E. coli recombinante. 15

Figura 6 - Fórmula estrutural do monômero, 3-hidroxibutirato (a), e do polímero Poli3-hidroxibutirato (b)

Figura 7 - Esquema das várias estratégias para engenharia metabólica em PHAs.20

Figura 8 - Rota de síntese de P3HB em E. coli recombinante. .23

Figura 9 - Conversão de acetofenona em $(R)$-feniletanol .30

Figura 10 - Conversão de xilose em xilitol 31

Figura 11 - Ciclo do NADPH por ação da transidrogenase UdhA na produção de PHB na Escherichia coli ..... .32

Figura 13 - Concentração de glicose no cultivo em frasco agitado em meio mineral suplementado ou não com $\mathrm{NaCl}(4 \mathrm{~g} / \mathrm{L})$

Figura 14 - Concentração de ácidos produzidos no cultivo em frasco agitado em

meio mineral suplementado ou não com $\mathrm{NaCl}(4 \mathrm{~g} / \mathrm{L})$

Figura 15 - Concentração de células total e residual em função do tempo para

cultivo em biorreator em meio suplementado com $\mathrm{NaCl}$ 48

Figura 16 - Teor e concentração de P3HB em função do tempo para cultivo em biorreator em meio suplementado com $\mathrm{NaCl}$

Figura 17 - Concentração de glicose no meio, e a produção de ácidos em função do tempo para cultivo em biorreator em meio suplementado com $\mathrm{NaCl}$ .52 


\section{Lista de tabelas}

Tabela 1 - Fator de conversão obtido nos ensaios em frasco agitado. ...................34

Tabela 2 - Composição do meio LB líquido ................................................. 36

Tabela 3 - Composição do meio mineral .................................................... 37

Tabela 4 - Composição da solução elementos traços ....................................... 37

Tabela 5 - Composição do meio utilizado nos experimentos em biorreator ..............38

Tabela 6 - Fator de conversão obtido para cada cepa no ensaio em frasco com meio mineral sem suplementação de $\mathrm{NaCl}$..........................................46

Tabela 7 - Fator de conversão obtido para cada cepa no ensaio em frasco com meio

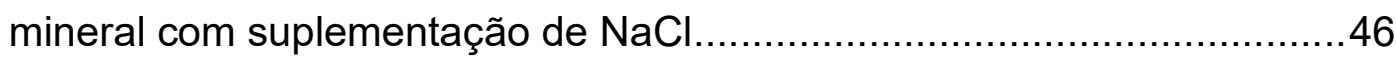

Tabela 8 - Velocidade específica de crescimento, fator de conversão e produtividade de P3HB para cultivo em biorreator 


\section{SUMÁRIO}

1 INTRODUÇÃO E JUSTIFICATIVA

2 REVISÃO BIBLIOGRÁFICA .17

2.1 Descoberta de PHAs e características do poli-3-hidroxibutirato 17

2.2 Cenário econômico da produção de PHAs .18

2.3 Uso de $\mathrm{NaCl}$ no meio de cultivo para aumento da produção de PHA ....21

2.4 Uso de E. coli recombinante para produção de poli-3-hidroxibutirato ..22

2.5 Função das enzimas com ação transidrogenase no metabolismo da Escherichia coli .24

2.6 Efeito de modificação do operon pntAB e do gene udhA, na produção de biomoléculas dependentes de NADPH .29

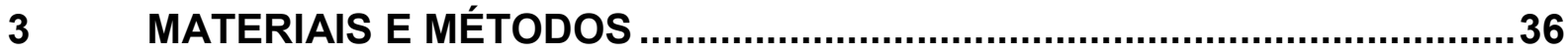

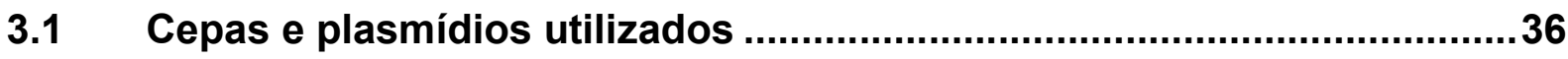

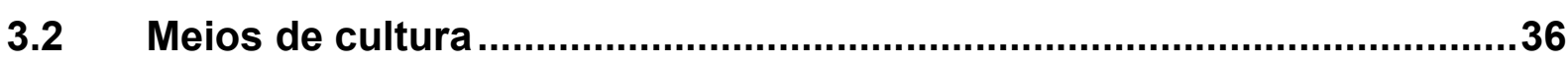

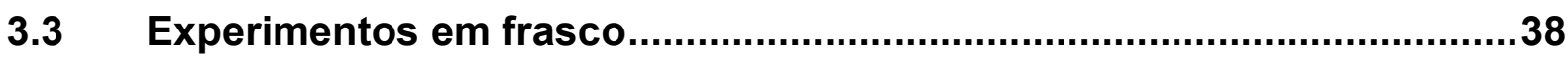

3.3.1 Pré-inóculo para experimento em frasco.............................................38

3.3.2 Inóculo para experimento em frasco ...................................................... 38

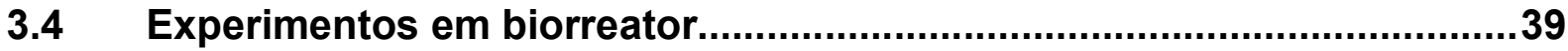

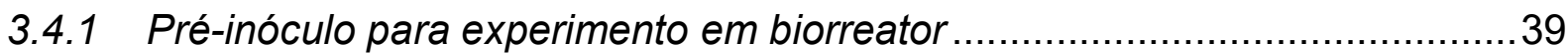

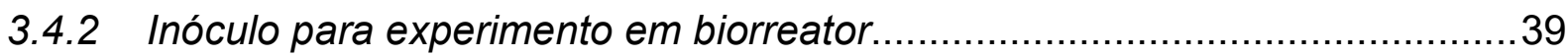

3.4.3 Procedimento e condições de cultivo em biorreator....................................39

3.5 Dosagem de glicose e ácidos ...........................................................40

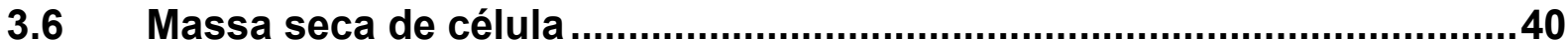

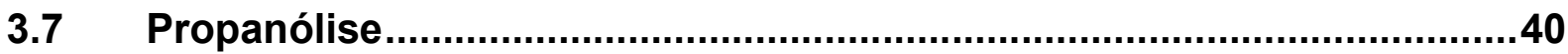

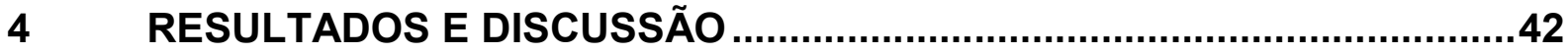

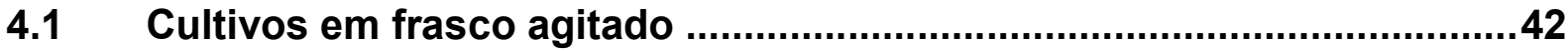

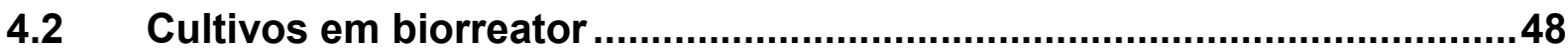

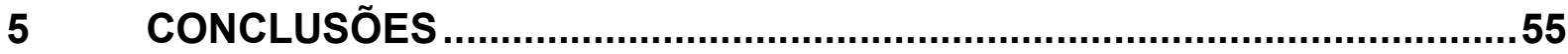

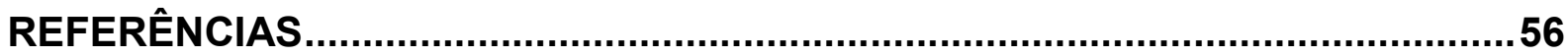


APÊNDICE A - DADOS DOS EXPERIMENTOS EM FRASCO AGITADO .64 APÊNDICE B - DADOS DOS EXPERIMENTOS EM BIORREATOR .68 APÊNDICE C - PARÂMETROS MONITORADOS E CONCENTRAÇÃO DE OUTROS METABOLITOS FORMADOS NOS EXPERIMENTOS EM BIORREATOR 


\section{INTRODUÇÃO E JUSTIFICATIVA}

Materiais plásticos são amplamente utilizados em diversas aplicações, dada a versatilidade, maleabilidade, abrangente gama de propriedades, e boa razão de custo e benefício destes materiais. A lista de produtos feitos de plástico é enorme, potes, garrafas, sacolas, copos descartáveis, embalagens, cadeiras, carcaça dos mais diversos aparelhos eletrônicos tão presentes na sociedade moderna, etc. (AMOS, 2017; GODINHO, 2005; PARKER, 2018; SOMBRIO, 2015; "What is the problem with plastic?", 2018).

Polímeros são materiais constituídos por cadeias de grandes dimensões Essas cadeias são compostas por moléculas menores que se repetem em um determinado padrão, conhecidas como monômeros. Dependendo dos tipos de monômeros, e do tipo de ligação entre eles, polímeros podem ter uma grande diversidade de propriedades. Plásticos são parte dessa classe de material, sendo classificados como polímeros sintéticos (BRADFORD, 2017). Os plásticos convencionais são, assim como diversos outros produtos, derivados de petróleo (ANDREESSEN; TAYLOR; STEINBÜCHEL, 2014).

Embora produtos plásticos sejam de grande benefício para a sociedade, possuem também um aspecto negativo, relacionado ao descarte destes materiais (AMOS, 2017; "Cinco gráficos que explicam como a poluição por plástico ameaça a vida na Terra", 2017; "What is the problem with plastic?", 2018; PARKER, 2018). Plásticos derivados de petróleo são polímeros não naturais e recalcitrantes, que podem levar centenas de anos para degradar na natureza, causando assim os mais diversos impactos ambientais como acúmulo em aterros (Figura 1), danos a vida marinha, a fauna e flora, e ainda contribuem para emissões de dióxido de carbono quando descartados através de incineração (ALI; JAMIL, 2016a; ANDREESSEN; TAYLOR; STEINBÜCHEL, 2014). 
Figura 1 - Acúmulo de lixo plástico em aterro sanitário

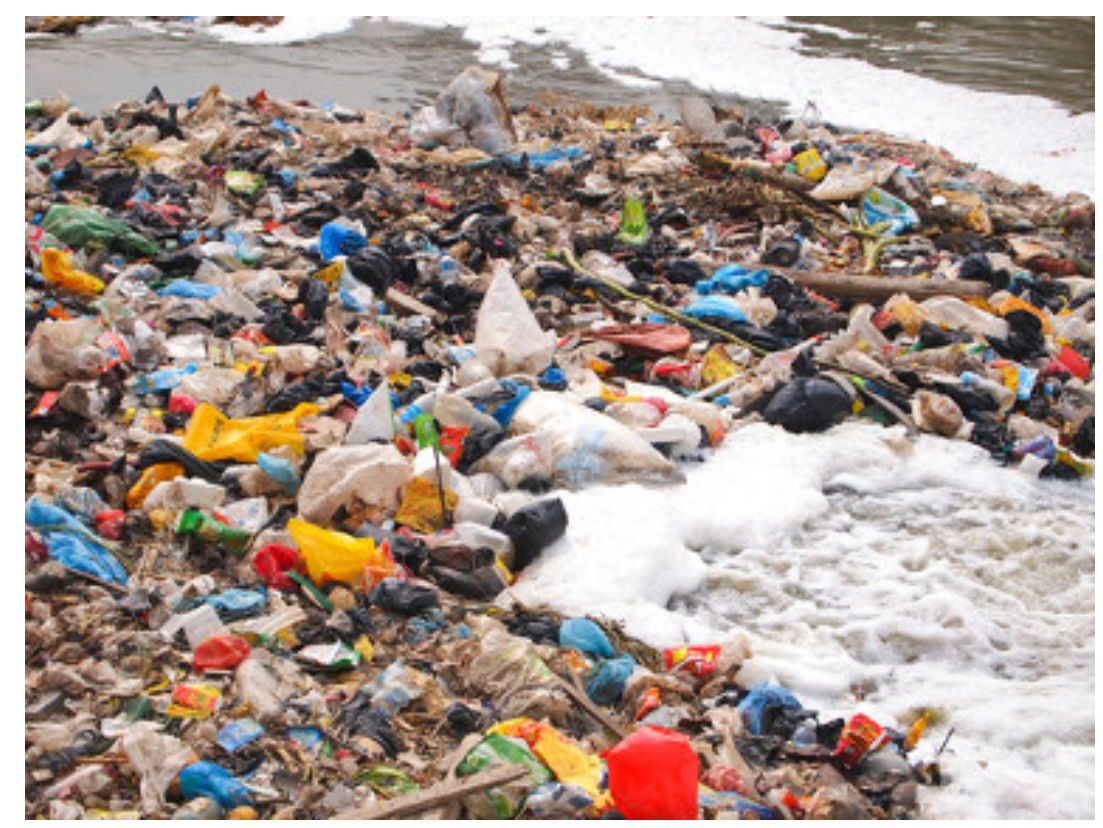

Fonte: Brasilescola.uol - Plástico-verde (2015)

Além disso, o contínuo esgotamento das reservas de petróleo exploráveis, e variações no preço do barril de petróleo são aspectos que pesam contra a produção de plásticos de origem fóssil (ALI; JAMIL, 2016a; ANDREESSEN; TAYLOR; STEINBÜCHEL, 2014; SOMBRIO et al., 2017). Devido a este cenário, esforços crescentes no desenvolvimento de plásticos produzidos a partir de biomassa, os chamados bioplásticos, tem sido feitos (ALI; JAMIL, 2016a, 2016b; ANDREESSEN; TAYLOR; STEINBÜCHEL, 2014; CHEN, 2009; KESHAVARZ; ROY, 2010).

Bioplásticos são capazes de sanar parcialmente os problemas inerentes do uso de plásticos convencionais (ALI; JAMIL, 2016a, 2016b; ANDREESSEN; TAYLOR; STEINBÜCHEL, 2014; KESHAVARZ; ROY, 2010). Muitos bioplásticos também possuem a vantagem de serem biodegradáveis (Figura 2), ou seja, são degradados naturalmente pela ação de microrganismos na natureza (ALI; JAMIL, 2016b; NIGMATULLIN et al., 2015). 
Figura 2 - Degradação de um filme de polihidroxialcanoato (PHA) em aproximadamente 50 dias
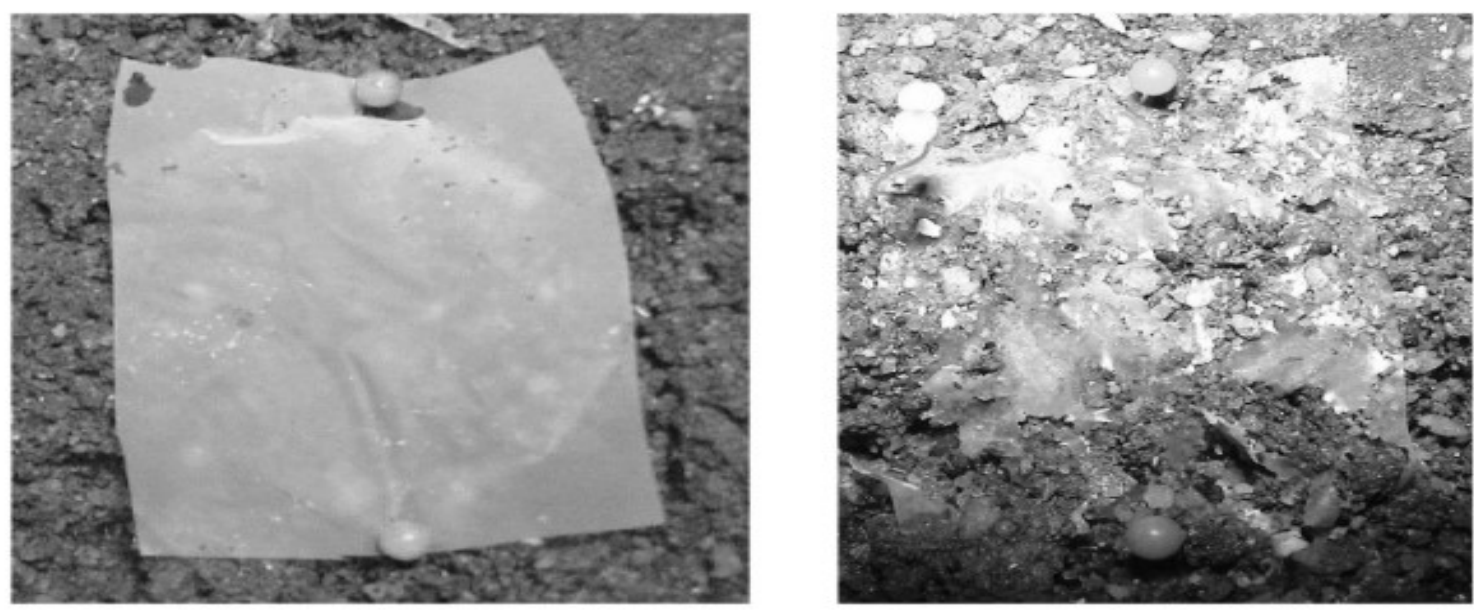

Fonte: SUDESH e IWATA (2008)

E ainda, caso bem administradas, algumas das matérias primas que podem ser utilizadas para a produção de bioplásticos, são fontes renováveis, conforme ilustrado na Figura 3.

Figura 3 - Ciclo do carbono de PHAs

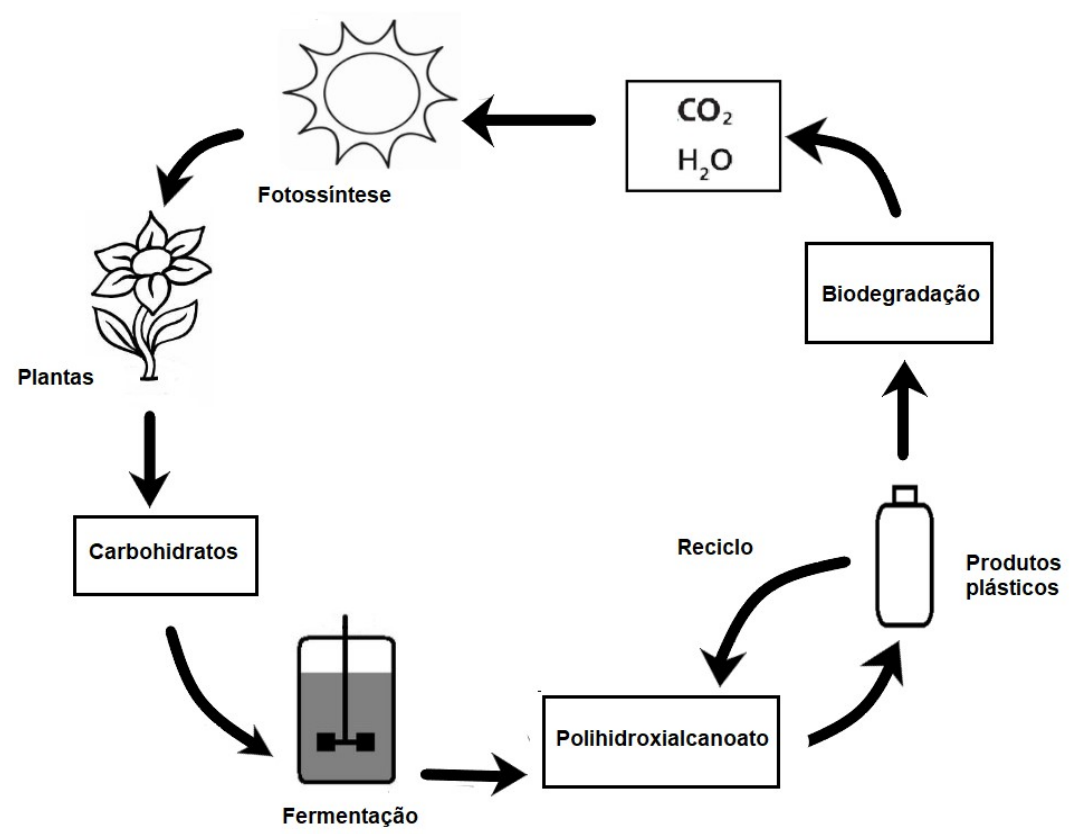

Fonte: Adaptado de LEE (1996) 
Uma classe de polímeros conhecidos como polihidroxialcanoatos, que podem ser usados na produção de bioplásticos, tem ganhado cada vez mais atenção dada à demanda por desenvolvimento de bioplásticos. PHAs são poliésteres que consistem de 100 a 30.000 monômeros (LEE, 1996). A estrutura geral de PHAs é apresentada na Figura 4.

Figura 4 - Estrutura geral dos polihidroxialcanoatos

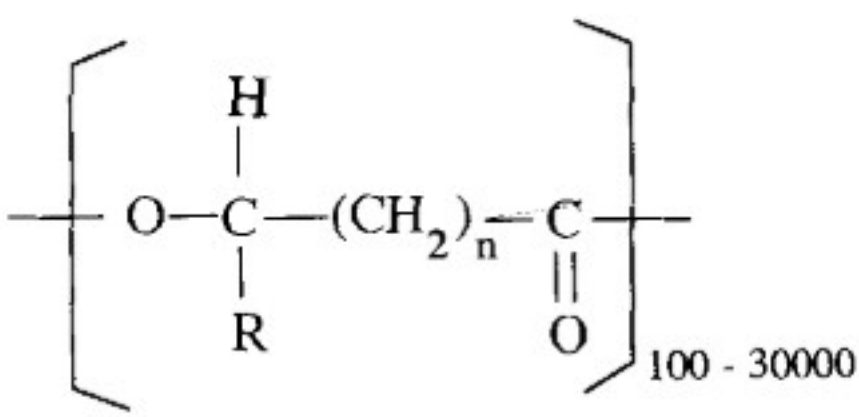

Onde $\mathrm{n}$ pode se repetir de 1 até 3 vezes e $\mathrm{R}$ pode ser hidrogênio ou os radicais metil, etil, propil, pentil e nonil

Fonte: LEE (1996)

PHAs são produzidos por bactérias em condições de excesso de fonte de carbono, mas limitação de elementos como Fósforo, Magnésio, Oxigênio, Nitrogênio e Enxofre, embora algumas bactérias como a Alcaligenes latus, Azotobacter vinelandii, e Escherichia coli recombinante não requerem limitação de nutrientes para a síntese de PHAs (CHOI; LEE, 1997). A Figura 5 apresenta o acúmulo de PHAs em E. coli recombinante. Segundo a literatura, bactérias podem alcançar um acúmulo de até mais de $80 \%$ da massa seca total da célula (ANDERSON; DAWES, 1990; CHEN, 2009; CHOI; LEE, 1999; HOLMES, 1985; LEE, 1996; PHILIP; KESHAVARZ; ROY, 2007; RAICHER, 2011; STEINBÜCHEL; FÜCHTENBUSCH, 1998; YANG et al., 2012). 
Figura 5 - Grânulos de PHAs acumulados em E. coli recombinante

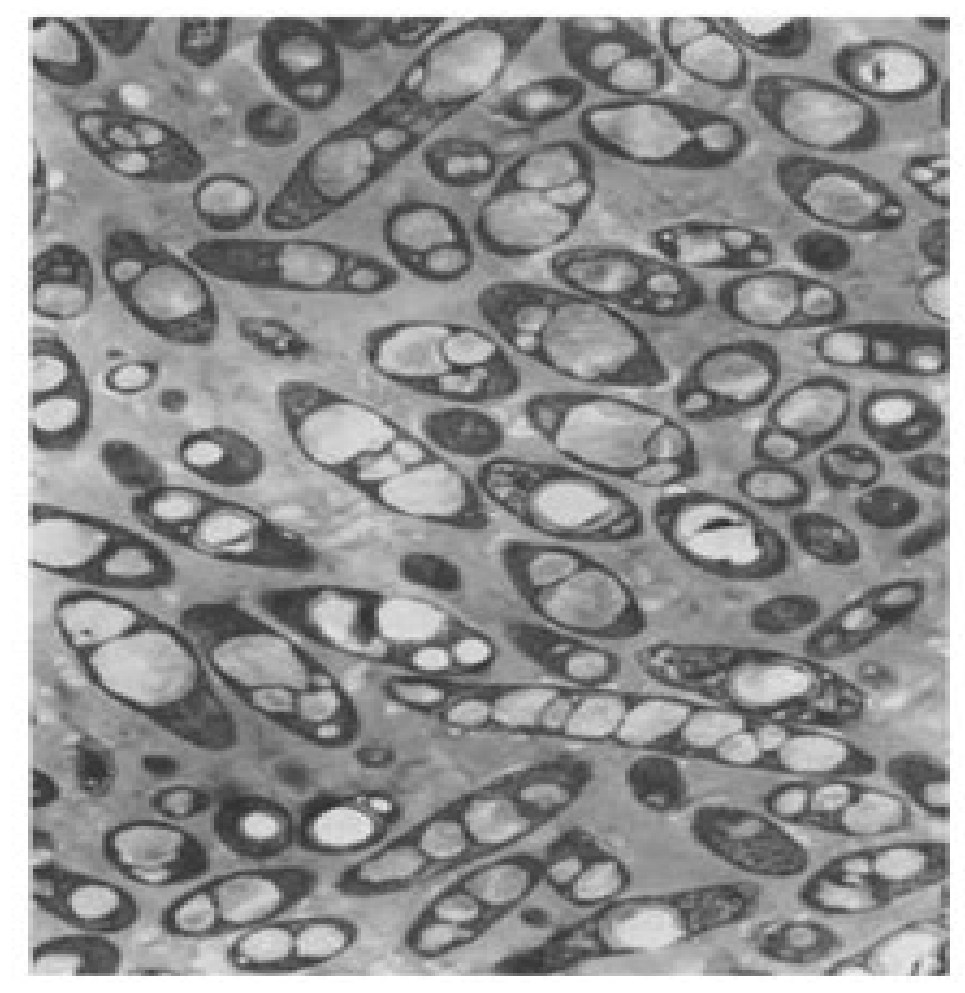

Fonte: LEE (1996)

Embora os bioplásticos possuam as citadas vantagens sobre os plásticos convencionais, existe uma grande desvantagem relacionada a produção de bioplásticos. O custo de produção de bioplásticos, especialmente PHAs como o poli3-hidroxibutirato (P3HB), é muito elevado se comparado ao de plásticos convencionais (GODINHO, 2005; SOMBRIO, 2015). Esse elevado custo de produção acaba afetando o preço de mercado dos PHAs. O preço do polietileno e do polipropileno (plásticos convencionais) é na faixa de 0,4-0,6 US\$/kg ("Real Time Price List”, 2019), enquanto que o preço do P3HB é na faixa de 3 - 5 US $\$ / k g$ (NARANJO et al., 2013). Por tal motivo, muitos trabalhos no campo de produção de bioplásticos, possuem como objetivo, melhorar a viabilidade econômica destes materiais (ALDOR; KEASLING, 2003; CHOI; LEE, 1999; LEE et al., 2013a, 2013b; LIN et al., 2015; MENG et al., 2015; PHITHAKROTCHANAKOON et al., 2015; SRIRANGAN et al., 2016; ZHENG et al., 2017). Os esforços principais destes trabalhos são: diminuir os custos de produção explorando a possibilidade do uso de fontes de carbono mais baratas, otimização do processo de extração dos polímeros, e aumentar a produtividade e conversão através do uso de Engenharia Metabólica e 
construção de bactérias recombinantes com vantagens em relação às cepas originais e outras bactérias naturalmente produtoras (GODINHO, 2005). E. coli recombinante, com o operon de síntese transferido de bactérias naturalmente produtoras, pode ser utilizada na produção de P3HB por possuir vantagens como crescimento rápido, facilidade na recuperação do polímero, dada a relativa fragilidade da sua parede celular e a não degradação do polímero produzido, visto que a $E$. coli não possui uma rota de despolimerização do P3HB (GODINHO, 2005). Contudo, estudos indicam a possibilidade de que a disponibilidade do cofator NADPH no metabolismo da $E$. coli pode ser um fator limitante na produção de moléculas cuja rota de síntese utiliza enzimas dependentes de NADPH, como é o caso da síntese de P3HB por expressão do operon da bactéria Ralstonia eutropha, em que uma das reações em sua rota de síntese é catalisada pela enzima acetoacetil-CoA redutase, que é dependente do cofator NADPH (CENTENO-LEIJA et al., 2014; HAVERKORN VAN RIJSEWIJK et al., 2016; HONG et al., 2016; SAUER et al., 2004; ZHENG et al., 2017). A função geral dos cofatores NADPH e NADH é de transportadores de elétrons. NADPH tem papel importante em reações catabólicas, onde energia é utilizada para biossíntese. Já o NADH esta envolvido com reações anabólicas, onde há geração de energia (HOLM et al., 2010).

No metabolismo da E. coli, a enzima piridina nucleotídeo transidrogenase ligada a membrana, e a piridina nucleotídeo transidrogenase solúvel, codificadas pelo operon pntAB e pelo gene $u d h A$, atuam na transferência de equivalentes redutores de $\mathrm{NADH}$ para $\mathrm{NADP}^{+}$e de $\mathrm{NADPH}$ para $\mathrm{NAD}^{+}$, respectivamente (HAVERKORN VAN RIJSEWIJK et al., 2016; HOLM et al., 2010; SAUER et al., 2004). Porém, alguns estudos apontam que essas enzimas podem catalisar a reação reversa dependendo das condições a qual a bactéria estiver exposta (JAN et al., 2013). Modificação no nível de expressão desses genes pode então ter efeito na síntese de moléculas dependentes de NADPH como o P3HB (FU et al., 2014; SANCHEZ et al., 2006; ZHENG et al., 2017). Em vista disso, este trabalho teve como objetivo realizar o cultivo em frasco agitado e biorreator, de três cepas, a $E$. coli MG1655, e duas mutantes derivadas desta, uma com o operon pntAB deletado, e outra com o gene $u d h A$ deletado, todas expressando o operon de síntese de P3HB da bactéria $R$. eutropha em um plasmídio (pBBR1MCS-2), para avaliar parâmetros de interesse como crescimento celular, e mais importante, a conversão de glicose a poli-3-hidroxibutirato. 


\section{REVISÃO BIBLIOGRÁFICA}

\subsection{Descoberta de PHAs e características do poli-3-hidroxibutirato}

O primeiro tipo de PHA foi descoberto em 1920 pelo microbiologista Francês Maurice Lemoigne. O polímero descoberto foi o poliéster poli-3-hidroxibutirato (P3HB), de monômero 3-hidroxibutirato, na forma de grânulos intracelulares na bactéria gram-positivo Bacillus megaterium (KESHAVARZ; ROY, 2010). Em 1950, trabalhos indicaram que o $\mathrm{P} 3 \mathrm{HB}$ funcionava como uma reserva de energia e carbono na bactéria do gênero Bacillus e que isso também era observado em muitas bactérias gram-negativas. Já em 1974 foi relatado por Rohwedder e Wallen a identificação dos monômeros 3-hidroxivalerato (3HV) e 3-hidroxihexanoato $(3 \mathrm{HHx})$ em extratos de clorofórmio de lodo de esgoto ativado. Por volta de 1983, Witholt et al. realizou a análise do polímero produzido pela bactéria Pseudomonas oleovorans, descobrindo que sua composição consistia principalmente do monômero 3hidroxioctanoato $(3 \mathrm{HO})$ e algumas unidades de $3 \mathrm{HHx}$. A descoberta de diversos monômeros e da possibilidade de polímeros compostos de combinações destes monômeros (copolímeros) foi de grande relevância no desenvolvimento de bioplásticos de $\mathrm{PHA}$, pois indicou a possibilidade de síntese de polímeros com uma gama muito maior de propriedades (SUDESH; ABE; DOI, 2000). Existem atualmente mais de 150 monômeros diferentes de PHA conhecidos (CHEN, 2009; NIGMATULLIN et al., 2015; YANG et al., 2012). Os monômeros de PHA são classificados como SCL (do inglês, Short Chain length) para monômeros com menos de 5 átomos de carbono, MCL (medium chain length) para monômeros com 6 a 14 átomos de carbono e LCL (long chain length) para monômeros com mais de 14 átomos de carbono (ANDREESSEN; TAYLOR; STEINBÜCHEL, 2014). P3HB é o polímero mais comum e estudado dentre os PHAs. A estrutura do P3HB é apresentada na Figura 6. 
Figura 6 - Fórmula estrutural do monômero, 3-hidroxibutirato (a), e do polímero Poli3-hidroxibutirato (b)

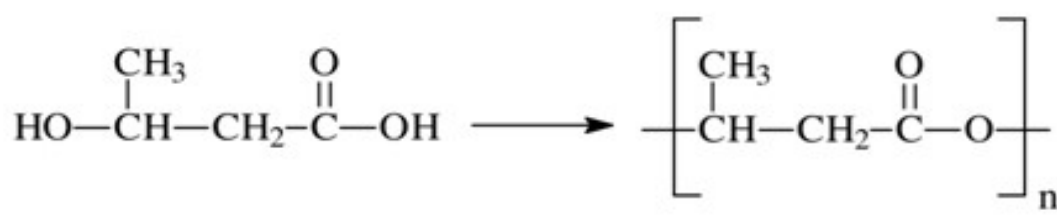

(a)

(b)

Fonte: $\mathrm{BUCCl}(2003)$

O P3HB é um material quebradiço, altamente cristalino e com temperatura de fusão elevada (ANDREESSEN; TAYLOR; STEINBÜCHEL, 2014). Sua cristalinidade fica na faixa de 55 a 80\% (LEE, 1996). É um polímero com propriedades similares ao polipropileno embora mais rígido e quebradiço (ANDERSON; DAWES, 1990; CHOI; LEE, 1997; HOLMES, 1985; LEE, 1996; STEINBÜCHEL; FÜCHTENBUSCH, 1998; SUDESH; ABE; DOI, 2000; SUDESH; IWATA, 2008).

Algumas das bactérias conhecidas, capazes de produzir o P3HB são: Ralstonia eutropha, Alcaligenes latus, Bacillus spp., Azotobacter vinelandii, Pseudomonas sp e mesmo Escherichia coli recombinante com os genes de biosíntese de P3HB da Ralstonia eutropha (LIN et al., 2015).

\subsection{Cenário econômico da produção de PHAs}

Alguns dos fatores que influenciam no preço de PHAs são a produtividade, a porcentagem de acúmulo, o fator de conversão e o preço da matéria prima e processos de recuperação (CHOI; LEE, 1999). Um fator que pesa muito no custo de produção de PHAs é o preço dos substratos usados. Avaliações econômicas do processo de produção de P3HB indicam que o preço das fontes de carbono pode contribuir com até $50 \%$ do custo total do processo (LIN et al., 2015). Algumas fontes de carbono comumente usadas para acúmulo de $\mathrm{P} 3 \mathrm{HB}$ em bactérias, e seus respectivos preços, aproximadamente, em dólar por tonelada métrica são metanol (184 US\$/t), sacarose (325 US\$/t), ácido acético (705 US\$/t), glicose (493 US\$/t) e frutose (617 US\$/t) (GANESH et al., 2015). 
Outro fator que pesa no alto custo de produção de PHAs é o processo de recuperação, onde métodos de extração por solventes requerem solventes caros e tóxicos como clorofórmio, cloreto de metileno, carbonato de propileno e dicloroetano. Outros métodos como o de digestão enzimática usado na produção de $\mathrm{P}(3 \mathrm{HB}-\mathrm{co}-$ 3HV) (outro tipo de PHA), também requer o uso de produtos químicos caros e processo complexo. E o método de recuperação por digestão usando hipoclorito resulta em degradação do PHA (CHOI; LEE, 1999; LEE, 1996).

Como mencionado anteriormente, o preço de venda do polietileno e polipropileno é na faixa de 0.4 - 0.6 US\$/kg ("Real Time Price List", 2019). Já o custo de produção do P3HB é de aproximadamente 3 - 5 US\$/kg (NARANJO et al., 2013). Em vista disso, o P3HB e outros PHAs precisam ter redução dos custos de produção e aumento da produtividade, para se tornarem economicamente competitivos com plásticos de origem fóssil. Estratégias para aumento da produtividade se concentram em esforços para permitir o uso de substratos mais baratos, métodos de extração mais eficientes e uso de modificação genética dos microrganismos com base em estudos de Engenharia Metabólica para a criação de células recombinantes capazes de maior produtividade (ANDERSON; DAWES, 1990; ANDREESSEN; TAYLOR; STEINBÜCHEL, 2014; CHOI; LEE, 1999; LEE, 1996; STEINBÜCHEL, 1995).

Alguns exemplos de trabalhos feitos com foco no uso de substratos mais baratos podem ser dados. O trabalho publicado em 2001 por Ahn et al., que mostrou a produção de $\mathrm{P} 3 \mathrm{HB}$ usando soro de leite como substrato, e E. coli recombinante expressando os genes de síntese de polihidroxialcanoato da Alcaligenes latus, em um processo semi-batelada com membrana para reciclo de células (AHN; PARK; LEE, 2001), a pesquisa de Arifin et al., focada na produção de P3HB usando como precursor a sacarose, e E. coli com o gene cscR deletado (ARIFIN et al., 2011), a tese feita por Raicher em 2011, que realizou uma análise econômica da produção de PHAs a partir de xilose excedente de uma biorrefinaria de co-geração de energia e etanol de segunda geração (RAICHER, 2011), o artigo de Shah et al. em 2014, que mostrou que a $E$. coli modificada na expressão dos genes que codificam as enzimas aldeído redutase e aldeído desidrogenase (alrd e aldH, respectivamente) é capaz de co-produzir P3HB e bioetanol, em processo aeróbico com glicerol como fonte de carbono (SHAH; CHIU; LAN, 2014), e um trabalho de 2015 por Bhatia et al., que apontou que a $E$. coli com o gene amilase da Panibacillus sp. e o operon de síntese 
de P3HB da Ralstonia eutropha é capaz de usar amido na produção de P3HB (BHATIA et al., 2015).

No que diz respeito ao uso de Engenharia Metabólica, uma revisão publicada por Aldor et al. em 2003, discute as estratégias gerais para melhora da produção de PHAs. Segundo o artigo, essas estratégias incluem manipulação externa de substrato, adição de inibidor, expressão de genes recombinantes, manipulação genética das células, construção proteica de enzimas biossintéticas de PHA e uso de modelos matemáticos, como ilustrado na Figura 7.

Figura 7 - Esquema das várias estratégias para engenharia metabólica em PHAs

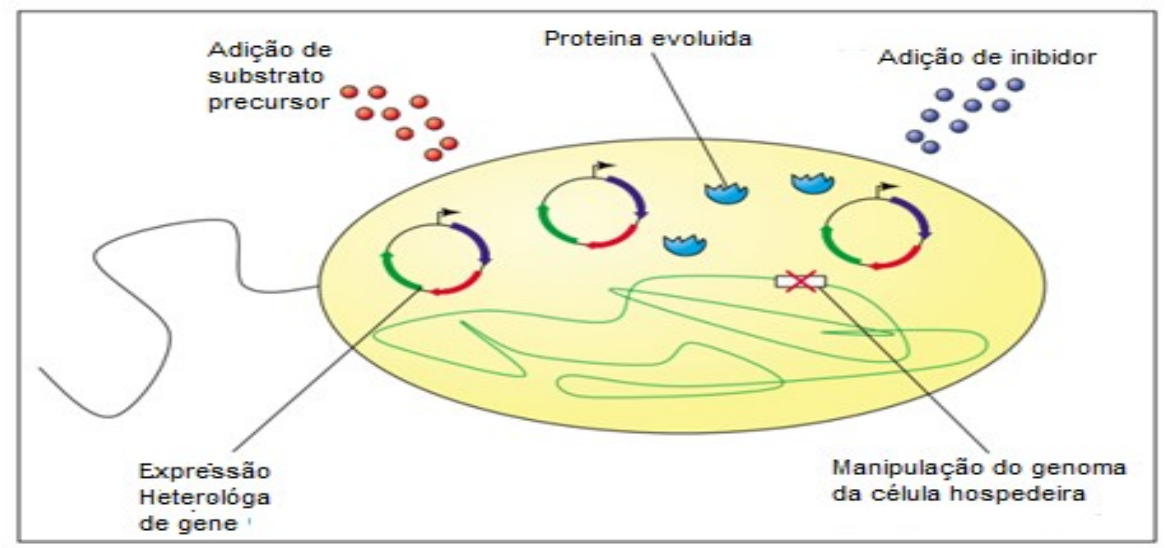

Fonte: Adaptado de ALDOR e KEASLING (2003)

Manipulação externa de substrato consiste em manipular a fonte de carbono alimentada a célula para direcionar o fluxo de carbono para as enzimas de biossíntese de polímeros. A adição de inibidores tem como intuito guiar os precursores de PHA ao inibir rotas não desejadas ou que limitam a expansão da cadeia do polímero. Expressão de genes recombinantes é a expressão heteróloga de genes contidos em plasmídios inseridos em microrganismos hospedeiros. Alguns dos microrganismos hospedeiros mais comuns são Ralstonia eutropha, Pseudomonas putida, Pseudomonas oleovorans e Escherichia coli. Manipulação do genoma da célula é feito com o intuito de eliminar rotas competitivas ou modificar as rotas nativas para intensificar a produção dos produtos desejados. Engenharia proteica envolve mutagênese e evolução molecular e é feita para otimizar a performance das enzimas chave, como a PHA sintase, de forma a favorecer a produção de polímeros com as propriedades desejadas. Aplicada todas essas 
estratégias, modelos matemáticos e genéticos, e análise proteômica e metabolômica, podem também ser implementados. Estes modelos podem ser usados para se estudar as células modificadas e apontar novas estratégias de otimização (ALDOR; KEASLING, 2003). Modelos podem até apontar rotas metabólicas ainda não identificadas.

\subsection{Uso de $\mathrm{NaCl}$ no meio de cultivo para aumento da produtividade de PHA}

Existem trabalhos na literatura que indicam que para além de reserva de carbono, polihidroxialcanoatos possuem um papel no sistema de resistência a estresse osmótico de muitas bactérias. Obruca et al. escreveu um artigo de revisão apontando os trabalhos mais importantes neste tema, como por exemplo o trabalho de Wang et al., onde foi realizado o cultivo da $E$. coli selvagem e de duas mutantes derivadas dessa, uma expressando os genes de síntese de P3HB, e outra expressando os genes para síntese e para despolimerização de P3HB (OBRUCA et al., 2018; WANG et al., 2009). As três cepas foram cultivadas em meio M9 com estresse osmótico elevado obtido pela adição de glicose na concentração final de $250 \mathrm{~g} / \mathrm{L}$. Os resultados indicaram que as cepas capazes de acumular P3HB apresentaram maior resistência (maior porcentagem de células vivas ao final do cultivo) ao meio de alta osmolaridade, do que a $E$. coli selvagem, que não é capaz de acumular P3HB (WANG et al., 2009).

Usando como base esses artigos que indicaram o papel do acúmulo de PHA como mecanismo de defesa a estresse osmótico, o trabalho de Passanha et al. estudou o efeito da adição de diferentes concentrações de $\mathrm{NaCl}$, no teor, concentração e conversão de PHA obtidos com a bactéria Cupriavidus necator DSMZ 545. Foi realizado cultivo em biorreator com meio nutriente e usando ácido acético de alta pureza (99\%) como fonte de carbono. As concentrações de $\mathrm{NaCl}$ testadas foram 3,5 g/L, 6,5 g/L, $9 \mathrm{~g} / \mathrm{L}, 12 \mathrm{~g} / \mathrm{L}$ e $15 \mathrm{~g} / \mathrm{L}$, além da condição de cultivo controle, onde não houve adição de $\mathrm{NaCl}$. Os resultados apontaram que nos cultivos realizados com concentração de $\mathrm{NaCl}$ de 3,5, 6,5 e $9 \mathrm{~g} / \mathrm{L}$, as bactérias obtiveram maior teor de PHA do que no cultivo realizado sem adição de $\mathrm{NaCl}$. A concentração mais alta de PHA obtida foi de 5,33 g/L (cultivo com 6,5 g/L de $\mathrm{NaCl}$ ). Foi relatado também que as bactérias cultivadas em meio com $9 \mathrm{~g} / \mathrm{L}$ de $\mathrm{NaCl}$ foram as que obtiveram maior conversão de substrato a produto, com valor de $0,41 \mathrm{~g} / \mathrm{g}, 30 \%$ a 
mais que o obtido na condição sem adição de $\mathrm{NaCl}$. Mas foi apontado que na alta concentração de $15 \mathrm{~g} / \mathrm{L}$, o NaCl teve efeito inibitório no acúmulo de PHA.

$\mathrm{O}$ artigo publicado por Abdulkarim et al. relata mais um efeito da adição de $\mathrm{NaCl}$ no meio de cultivo. Dentre os ensaios realizados neste trabalho, destaca-se o uso de concentrações de $0,5,10$ e $15 \mathrm{~g} / \mathrm{L}$ de $\mathrm{NaCl}$, em meio nutriente $\mathrm{n}^{\circ} 2$, para cultivo de Escherichia coli a $37^{\circ} \mathrm{C}$. Os resultados obtidos apontaram que o uso de 5 $\mathrm{g} / \mathrm{L}$ de $\mathrm{NaCl}$ teve efeito positivo no crescimento das células em relação ao meio sem adição do sal, mas concentrações acima de $5 \mathrm{~g} / \mathrm{L}$ tiveram efeito inibitório, afetando negativamente o crescimento das células (ABDULKARIM; FATIMAH; ANDERSON, 2009).

\subsection{Uso de E. coli recombinante para produção de poli-3-hidroxibutirato}

Muitos trabalhos onde $\mathrm{O}$ intuito é melhorar a produtividade, conversão e acúmulo de PHAs como o P3HB estão focados no estudo de células recombinantes. (ALDOR; KEASLING, 2003; CHOI; LEE, 1999; LEE et al., 2013a, 2013b; LIN et al., 2015; MENG et al., 2015; PHITHAKROTCHANAKOON et al., 2015; SRIRANGAN et al., 2016; ZHENG et al., 2017). Cepas de bactérias recombinantes podem apresentar vantagens sobre as cepas originais e outras bactérias naturalmente produtoras de polímeros como o $\mathrm{P} 3 \mathrm{HB}$. Bactérias como a $E$. coli, são bactérias muito estudas bioquimicamente, fisiologicamente e geneticamente, sendo assim ideais para a expressão de genes de outras bactérias. Vantagens do uso de E. coli recombinante para a produção de PHAs são, crescimento rápido para uma alta concentração celular, resultando em maior produtividade, alta porcentagem de acúmulo de polímero (relatos de ate 80 a $90 \%$ da massa seca de célula ao final do cultivo), capacidade de utilizar diversas fontes de carbono mais baratas (lactose, xilose, proteína do leite, glicerol, etc.), facilidade na recuperação e purificação de PHAs visto que a $E$. coli é uma bactéria com membrana celular relativamente frágil, facilitando o rompimento da célula, e o fato de que a $E$. coli não possui um sistema de despolimerização do PHA já que não é uma produtora natural, não havendo então degradação desses polímeros. Além disso, mutantes especificas podem ser construídas para serem capazes de produzir copolímeros como $\mathrm{P}(3 \mathrm{HB}-\mathrm{co}-3 \mathrm{HV})$ (ANDERSON; DAWES, 1990; CHEN, 2009; CHOI; LEE, 1997; KESHAVARZ; ROY, 
2010; LEE, 1996; STEINBÜCHEL; FÜCHTENBUSCH, 1998; SUDESH; ABE; DOI, 2000).

E. coli recombinante com o operon de síntese de $\mathrm{P} 3 \mathrm{HB}$ da bactéria $R$. eutropha pode ser usada na produção de P3HB (CHEN, 2009; JARI et al., 2015; LIN et al., 2015; SUDESH; ABE; DOI, 2000). A molécula precursora nesta rota de síntese é o acetil-CoA. Três reações a partir do acetil-CoA são realizadas até a obtenção do $\mathrm{P} 3 \mathrm{HB}$, sendo cada uma dessas reações catalisada por uma enzima codificada no operon recebido da $R$. eutropha. Na primeira reação, catalisada pela enzima $\beta$-cetotiolase (codificada pelo gene phaA), duas moléculas de acetil-CoA são condensadas a acetoacetil-CoA. Na segunda reação, catalisada pela enzima acetoacetil-CoA redutase (codificada pelo gene phaB), $\mathrm{O}$ acetoacetil-CoA é reduzido a (R)-3-hidroxibutiril-CoA. Na terceira reação, catalisada pela enzima P3HB sintase (codificada pelo gene phaC), a polimerização do (R)-3-hidroxibutiril-CoA é realizada, obtendo-se assim o P3HB (BHATIA et al., 2015; HONG et al., 2016; LEE et al., 2013a; ZHANG et al., 2015, 2014; ZHENG et al., 2017). A Figura 8 ilustra esta rota de síntese.

Figura 8 - Rota de síntese de P3HB em E. coli recombinante

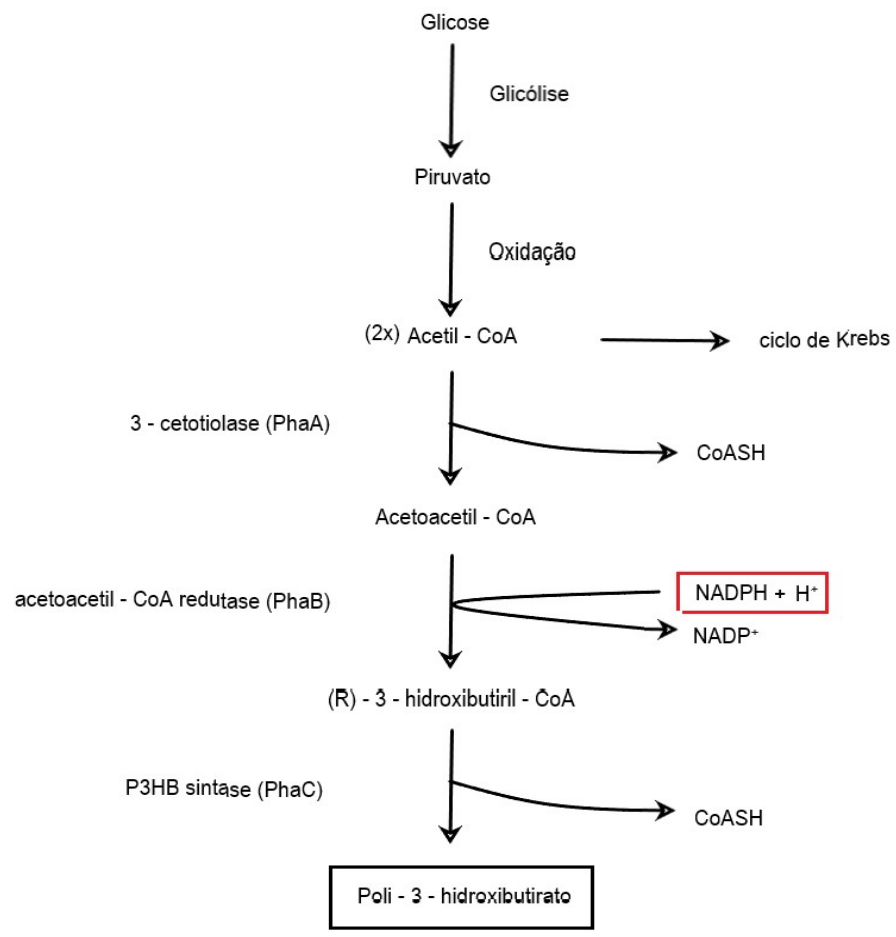


Pode-se observar que a reação catalisada pela enzima acetoacetil-CoA redutase é dependente do cofator NADPH (ALDOR; KEASLING, 2003; FRY et al., 1991; LEE, 1996; STEINBÜCHEL; FÜCHTENBUSCH, 1998; WANG et al., 2012). Existem trabalhos na literatura que indicam a possibilidade de que a quantidade de NADPH disponível na $E$. coli não é suficiente para produção de algumas biomoléculas cuja síntese depende do mesmo, ou seja, a quantidade de NADPH disponível é um fator limitante na produção de moléculas como o P3HB (CENTENOLEIJA et al., 2014; HAVERKORN VAN RIJSEWIJK et al., 2016; HONG et al., 2016; SAUER et al., 2004; ZHENG et al., 2017). Há também uma boa quantidade de trabalhos na literatura onde alterações foram feitas na $E$. coli para se aumentar a quantidade de NADPH disponível e consequentemente a quantidade de P3HB produzido (CENTENO-LEIJA et al., 2014; HOLM et al., 2010; HONG et al., 2016; WANG et al., 2015).

Trabalhos focados no aumento da produção de P3HB usando inserção de plasmídios (para expressão heteróloga), inserção de cópias de gene no cromossomo, deleção e super-expressão de genes (expressão homóloga) também podem ser encontrados na literatura. Dois exemplos são os trabalhos de Lee et al. e Zhang et al. $\mathrm{O}$ artigo publicado por Lee et al. revelou que a super-expressão dos genes $f b a A$ e tpiA, que codificam enzimas que participam da rota glicolítica na $E$. coli, é capaz de aumentar a produção de acetil-CoA, e consequentemente de P3HB, visto que o acetil-CoA é um precursor necessário para a síntese de P3HB (LEE et al., 2013a). Em 2015, Zhang et al. publicou um artigo sobre produção de P3HB em E. coli recombinante com múltiplas cópias do gene yfjb, que codifica a enzima NAD Kinase, inseridas em seu cromossomo. Esta enzima converte $\mathrm{NAD}^{+}$para $\mathrm{NADP}^{+}$, que num cenário de alta demanda por NADPH, acaba sendo convertido a NADPH pela ação das enzimas transidrogenase, beneficiando as rotas de síntese dependentes de $\mathrm{NADPH}$, como o P3HB. O artigo relata que esta cepa conseguiu produção superior ao tipo selvagem usado como controle (ZHANG et al., 2015).

\subsection{Função das enzimas com ação transidrogenase no metabolismo da Escherichia coli}

As rotas pela qual o metabolismo da E. coli regenera NADPH são, a fase oxidativa da via das pentoses-fosfato pela ação das enzimas glicose-6-fosfato 
desidrogenase e 6-fosfogluconato desidrogenase (codificadas pelos genes zwf e gnd, respectivamente), no ciclo do ácido cítrico pela ação da enzima isocitrato desidrogenase, pela ação da enzima piridina nucleotídeo transidrogenase de membrana e da enzima piridina nucleotídeo transidrogenase solúvel (codificadas pelo operon pntAB e pelo gene $u d h A$, respectivamente), e em menor parte pela ação da enzima málica (BOONSTRA et al., 1999; CHIN et al., 2009; CHOU; MARX; SAUER, 2015; FU et al., 2014; LONG et al., 2018; PONTRELLI et al., 2018; SAUER et al., 2004). O trabalho de Sauer et al. de 2004, apontou que, durante crescimento aeróbico em batelada com glicose, a transidrogenase PntAB produziu entre 35 a $45 \%$ do NADPH necessário para biossíntese, enquanto a enzima isocitrato desidrogenase e a rota pentose fosfato produziram na faixa de 20 a $25 \%$ e 35 a $45 \%$, respectivamente (SAUER et al., 2004).

Tipicamente, microrganismos possuem ou apenas uma das duas isoformas da enzima transidrogenase, ou nenhuma. Mas uma exceção são os microrganismos da família Enterobacteriaceae, bactérias Gram-negativas, da qual a Escherichia coli faz parte. Essas bactérias possuem ambas as isoformas, a transidrogenase ligada a membrana, e a transidrogenase solúvel (BOONSTRA et al., 1999; FU et al., 2014; SAUER et al., 2004). Essas enzimas possuem papel no controle da disponibilidade dos cofatores NADH e NADPH, mas ainda não há um consenso absoluto no papel específico de cada uma dessas enzimas no metabolismo dessas bactérias (HAVERKORN VAN RIJSEWIJK et al., 2016; JAN et al., 2013; SAUER et al., 2004).

Em bactérias, a transidrogenase ligada à membrana se encontra na região interna da membrana plasmática, e catalisa a transferência reversível de equivalentes de íons hidreto entre $0 \mathrm{NAD}^{+}$e $\mathrm{NADP}^{+}$, em reação acoplada a translocação de prótons através da membrana (Equação 1).

$$
N A D H+N A D P^{+}+n H_{\text {out }}^{+} \longleftrightarrow N A D^{+}+N A D P H+n H_{\text {in }}^{+}
$$

Onde o $n$ na Equação 1 é o número de prótons bombeados pela membrana, o subscrito in se refere a região do citoplasma e out se refere a região de periplasma. Esta enzima possui duas subunidades, a a e $\beta$ (acopladas como um tetrâmero $\alpha_{2} \beta_{2}$ ), que são codificadas pelos genes pntA e pntB (que constituem o operon pntAB). $A$ reação no sentido da oxidação do $\mathrm{NADH}$ e redução do $\mathrm{NADP}^{+}$é dependente de 
energia, obtida pela translocação de prótons através da membrana (AHMAD; GLAVAS; BRAGG, 1992; ANDERLUND et al., 1999; BRAGG, 1998; HOEK; RYDSTROM, 1988; MEULLER et al., 2001; SAUER et al., 2004; VOORDOUW; VIES; THEMMEN, 1983).

A transidrogenase solúvel, codificada pelo gene udhA na E. coli, possuí 466 aminoácidos, é uma flavoproteína encontrada no citoplasma de apenas algumas bactérias. Também catalisa a transferência reversível de equivalentes de íons hidreto entre o $\mathrm{NAD}^{+}$e $\mathrm{NADP}^{+}$, mas não é dependente de energia conforme indicado na Equação 2.

$$
N A D H+N A D P^{+} \longleftrightarrow N A D^{+}+N A D P H
$$

Existe na literatura diversos trabalhos dedicados a tentar esclarecer o papel específico dessas enzimas no metabolismo de bactérias como a $E$. coli. Discutindoos em ordem cronológica, em 1983 o trabalho publicado por Voordouw et al., sugeriu que a enzima transidrogenase ligada a membrana tem como função principal, catalisar a reação no sentido de geração de $\mathrm{NADPH}$, enquanto que a transidrogenase solúvel, catalisa principalmente na direção de geração de NADH (VOORDOUW; VIES; THEMMEN, 1983).

Num trabalho publicado por Hoek et al. em 1988, que tinha como intuito entender o papel fisiológico da transidrogenase ligada a membrana especificamente, foi sugerido que as características termodinâmicas desta enzima permite catalisação da reação como resposta rápida tanto para o cenário de necessidade de regeneração de $\mathrm{NADPH}$, quanto para o cenário de necessidade de consumo de energia, nas situações onde não há rotas mais eficientes de se obter este cofator ou energia, agindo assim como um "tampão", prevenindo a baixa excessiva de NADPH ou o esgotamento de energia no metabolismo (HOEK; RYDSTROM, 1988).

Já em 1999, o trabalho publicado por Boonstra et al, (BOONSTRA et al., 1999) foi o primeiro a relatar que o gene $u d h A$ da $E$. coli, que até então tinha função desconhecida, codifica a enzima transidrogenase solúvel, fazendo então da $E$. coli o primeiro organismo possuidor dos dois tipos de transidrogenase a ser documentado. $\mathrm{O}$ artigo também menciona que o fato de que a presença da NADPH aumenta a atividade da transidrogenase solúvel, enquanto a presença de $\mathrm{NADP}^{+}$inibi a 
atividade desta enzima, sugere que o papel fisiológico desta transidrogenase é a conversão de NADPH para NADH (BOONSTRA et al., 1999).

O já citado artigo de Sauer et al. também analisou as funções da transidrogenase ligada a membrana e da transidrogenase solúvel no metabolismo da E. coli MG1655. Usando mutantes definidas e análise de fluxo metabólico, o trabalho realizado apontou que durante crescimento aeróbico em glicose, o catabolismo da glicose gerou menos NADPH que o necessário para biossíntese, mas a transidrogenase ligada a membrana foi uma grande fonte de NADPH. Já a transidrogenase solúvel, foi essencial para crescimento em condições metabólicas de excesso de NADPH, como por exemplo, o crescimento em acetato. Também é relatado que a transidrogenase solúvel não teve função aparente durante crescimento em glicose, enquanto que a cepa com deleção do gene pntAB teve velocidade específica de crescimento menor que a cepa selvagem, durante a fase exponencial do crescimento em glicose. Sugere ainda que a expressão desses genes seja modulada pelo estado oxidativo do metabolismo da célula, visto que aumento ou diminuição na formação de NADPH, influenciam no nível de transcrição do operon pntAB e do gene udhA (SAUER et al., 2004).

Enquanto o trabalho mencionado de Hoek et al. foi focado no papel fisiológico da transidrogenase ligada a membrana, o artigo de Zhao et al., de 2008, teve como intuito tentar esclarecer o papel da transidrogenase solúvel na $E$. coli. Cultivo em acetato, com uso de cepas recombinantes que tiveram o gene udhA deletado, foi realizado (ZHAO et al., 2008). O artigo apontou que o papel fisiológico da transidrogenase solúvel codificada pelo gene udhA é converter NADPH para NADH para geração de energia no ciclo de respiração, durante crescimento em acetato, cujo catabolismo acaba gerando excesso de NADPH, estando assim, em concordância com o que fora apontado no trabalho de Sauer et al. Holm et al., em 2010, também publicou um trabalho com resultados similares para a função da transidrogenase solúvel, onde cepas com modificações que levavam a um excesso de NADPH, apresentaram aumento considerável do fluxo de transidrogenase, da transidrogenase solúvel em especial, para diminuir o excesso de NADPH pela reação na direção de geração de $\mathrm{NADH}$. Nesse aspecto então, o artigo concluiu que a transidrogenase solúvel é ativada durante condições metabólicas em que há excesso de NADPH e que um papel importante da transidrogenase solúvel é manter a homeostase de NADH (HOLM et al., 2010). 
Dois trabalhos onde evolução laboratorial foi utilizada, o de Chou et al., de 2015 e o de Long et al., de 2018, também apontaram resultados similares, para o possível papel fisiológico das duas enzimas com ação transidrogenase da E. coli. No trabalho de Chou et al., duas cepas foram utilizadas, a selvagem (como controle) e uma cepa com baixa geração de NADPH, devido a deleção de genes da fase oxidativa da via pentose-fosfato e da via Entner-Doudoroff. Populações dessas duas cepas passaram por um cultivo em glicose, com duração suficiente para que mil gerações ocorressem, e as mutações ocorridas por seleção natural foram estudadas. Foi indicado que houve mutações de supra-regulação do operon pntAB na cepa que era deficiente na geração de NADPH, como uma adaptação para que através da maior atividade da enzima transidrogenase ligada a membrana, os níveis de NADPH fossem recuperados (CHOU; MARX; SAUER, 2015). Em contra partida, no trabalho de Long et al., uma cepa de E. coli teve o gene pgi, que catalisa a primeira reação na rota glicolítica, deletado, o que forçou o fluxo de carbono para a rota pentose-fosfato, resultando em excesso de NADPH e uma queda na velocidade de crescimento de $70-80 \%$. Após evolução laboratorial por cultivo em glicose, as mutações ocorridas foram estudadas, e foi apontado potencial supra-regulação do gene $u d h A$ e infra-regulação do operon pntAB, como adaptação para converter o NADPH em excesso, para NADH (LONG et al., 2018).

Haverkorn van Rijsewijk et al. investigou, em 2016, a regulação do operon pntAB e gene $u d h A$ estudando a influência do meio e de perturbações genéticas, nos níveis de transcrição. Foi encontrado que, diferente do que havia sido sugerido por Sauer et al., 2004, a regulação de ambas as enzimas transidrogenase não é uma resposta direta a alta ou baixa produção de NADPH, mas de forma indireta através de nível de nutrientes e da velocidade de crescimento da célula, de forma que acompanha a demanda da célula pelos cofatores NADPH e NADH. Os resultados obtidos apontaram também o papel principal de auxílio de biossíntese para a transidrogenase PntAB, e relaciona a transidrogenase UdhA a respiração (HAVERKORN VAN RIJSEWIJK et al., 2016).

Por fim, expandindo o mencionado trabalho de 2008, ZHAO et al., em 2018, publicou mais um trabalho sobre o papel da transidrogenase UdhA no metabolismo da E. coli. O experimento realizado consistiu em cultivo de cepas da E. coli MG1655, incluindo cepa com deleção do gene $u d h A$, em meio de cultura mínimo suplementado com MOPS ( $\mathrm{pH}$ de 7,4), com acetato como fonte de carbono, para 
determinação da velocidade específica de crescimento, e subsequente cultivo em meio no $\mathrm{pH}$ de 4,9, também com acetato como fonte de carbono, para teste de resistência a acidez. Assim como fora apontado pelo trabalho anterior, a cepa com deleção do gene udhA cresceu menos que a controle no cultivo com acetato, apontando que a transidrogenase UdhA é essencial para a $E$. coli no crescimento em meios em que há excesso de geração de NADPH, em detrimento a geração de $\mathrm{NADH}$, já que a transidrogenase UdhA é capaz de converter o NADPH em excesso, em NADH. Foi apontado também que a baixa quantidade de NADH na cepa com deleção do gene $u d h A$, teve efeito negativo no nível de expressão de seis genes envolvidos com um dos quatro sistemas de resistência a meios ácidos da $E$. coli, os genes gadA, gadB, gadC, gadE, hdeA e hdeB. Em vista disso, o artigo concluiu que a transidrogenase UdhA também tem um papel na expressão de genes relacionados ao sistema de resistência a meios ácidos da $E$. coli no crescimento em acetato (ZHAO et al., 2018).

Em resumo, a literatura indica que, em geral, a transidrogenase ligada a membrana, codificada pelo operon pnt $A B$ catalisa a reação de transferência de íns hidreto, na direção de consumo de $\mathrm{NADH}$ e geração de $\mathrm{NADPH}$, enquanto que transidrogenase solúvel, codificada pelo gene $u d h A$, catalisa a reação de transferência de íons hidreto, nas direção de consumo de NADPH e geração de $\mathrm{NADH}$.

\subsection{Efeito de modificação do operon pntAB e do gene udhA, na produção de biomoléculas dependentes de NADPH}

Também existe na literatura, trabalhos onde deleção ou super-expressão do operon pntAB e do gene $u d h A$ foi realizado com o intuito de se estudar o efeito destas alterações, na síntese de moléculas dependentes de NADPH. Dentre os estudos envolvendo o operon pntAB, podem ser citados os trabalhos de Weckbecker e Hummel, Kabus et al., Akinterinwa et al., Bastian et al., e Rathnasingh et al., muito embora estes trabalhos não envolvam a produção de P3HB especificamente.

No trabalho de Weckbecker e Hummel, publicado em 2004, super-expressão do operon pntAB foi feito com intuito de aumentar a conversão de acetofenona para (R)-feniletanol (WECKBECKER; HUMMEL, 2004), pela maior regeneração de 
NADPH. A conversão de acetofenona para (R)-feniletanol é dependente de NADPH, conforme ilustrado na Figura 9.

Figura 9 - Conversão de acetofenona em $(R)$-feniletanol

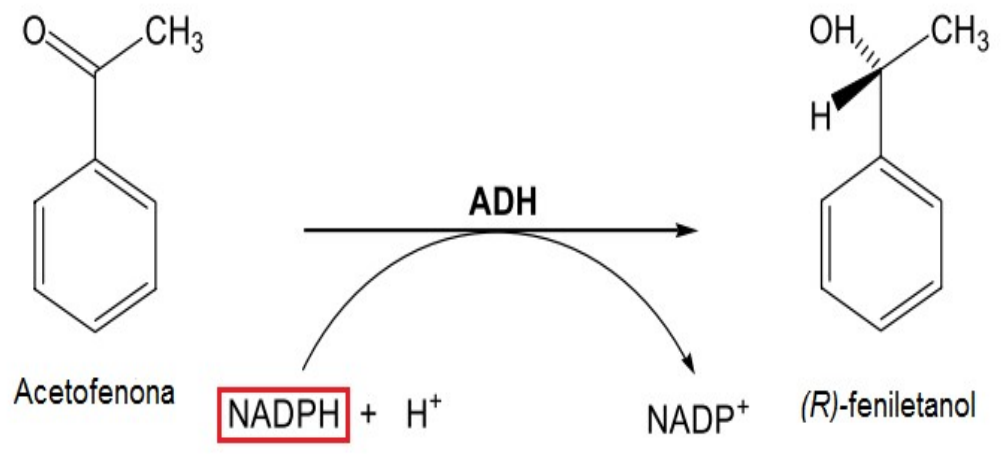

Fonte: Adaptado de Weckbecker e Hummel (2004)

O estudo relata que $19 \%$ da acetofenona é convertida em (R)-feniletanol, em um cultivo de 12 horas, na cepa sem super-expressão do pntAB. Já a cepa com super-expressão obteve, num cultivo sob as mesmas condições, conversão de $66 \%$ da acetofenona em (R)-feniletanol, indicando que a transidrogenase PntAB permitiu maior regeneração de NADPH e foi benéfica para a síntese de uma molécula cuja rota é dependente do mesmo (WECKBECKER; HUMMEL, 2004).

Já no trabalho publicado por Kabus et al., de 2007, foi realizado a expressão do operon pntAB da $E$. coli na bactéria Corynebacterium glutamicum, com o intuito de aumentar a quantidade de NADPH e estudar seu efeito na produção de L-lisina. A biossíntese de L-lisina na C. glutamicum pode ocorrer por duas rotas metabólicas e ambas precisam de 4 mols de NADPH por mol de lisina produzida a partir de oxaloacetato. $\mathrm{O}$ artigo relata que a presença da transidrogenase PntAB aumentou a produção de lisina da cepa de C. glutamicum mutante em todas as fontes de carbono testadas (glicose, frutose, sacarose) (KABUS et al., 2007).

Akinterinwa et al., em 2011, construiu uma E. coli recombinante capaz de produzir xilitol em cultivo anaeróbio, usando mistura de glicose e xilose como fonte de carbono. A reação de síntese de xilitol a partir de xilose é realizada pela enzima xilose redutase (codificada pelo gene $c b X R$ ), que é dependente de NADPH, conforme indicado na Figura 10. 
Figura 10 - Conversão de xilose em xilitol

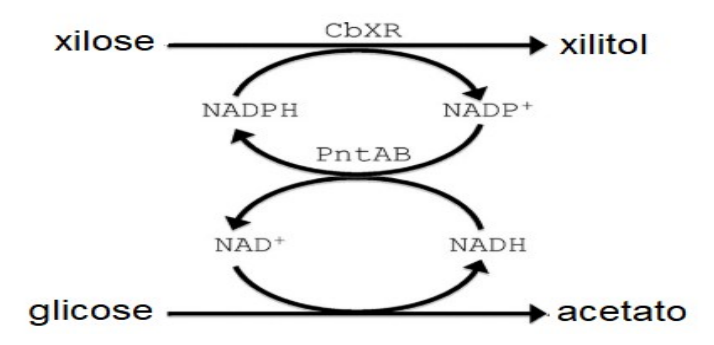

Fonte: Adaptado de Akinterina e Cirino (2011)

Deleção do gene pntA (que codifica uma das duas subunidades da enzima transidrogenase ligada a membrana), resultou em redução de $55 \%$ na produção de xilitol, indicando que a enzima transidrogenase ligada a membrana contribuía para a síntese de xilitol ao regenerar o cofator NADPH, visto que a ausência da mesma afetou negativamente a produção de xilitol, diminuindo em mais de $50 \%$ o fator de conversão. (AKINTERINWA; CIRINO, 2011).

No artigo de Bastian et al., de 2011, aumento da produção de isobutanol a partir de glicose em processo anaeróbio com $E$. coli modificada, foi obtido através da super-expressão do operon pntAB. A rota de síntese de isobutanol é dependente de NADPH e a super-expressão da transidrogenase ligada a membrana se provou suficiente para elevar a conversão de isobutanol para o valor máximo teórico em condições anaeróbias. Após cultivo de $24 \mathrm{~h}$ em meio M9, a concentração de isobutanol foi de apenas $1 \mathrm{~g} / \mathrm{L}$ para a cepa controle e de 8,5 g/L para a cepa com super-expressão do pntAB, e a produtividade foi de 0,015 g/L.h.OD e 0,09 g/ L.h.OD, para a cepa controle e cepa com super-expressão do pntAB, respectivamente (BASTIAN et al., 2011).

Em estudo publicado em 2012 por Rathnasingh et al., cepas de E. coli modificadas capazes de produzir ácido 3-hidroxipropiônico (monômero do PHA poli3-hidroxipropiônico) foram desenvolvidas, e dado que a reação de síntese de ácido 3-hidroxipropiônico a partir de seu precursor, o malonil-CoA, é dependente do cofator NADPH, o trabalho estudou estratégias para aumentar a regeneração de NADPH na E. coli. Uma das estratégias testadas foi a super-expressão do operon pntAB, estratégia que se provou bem sucedida, aumentando a produção de ácido 3hidroxipropiônico em 33\% (RATHNASINGH et al., 2012). 
Nota-se então que, em todos estes trabalhos, a enzima codificada pelo operon pntAB teve efeito na produção de moléculas cuja síntese depende de NADPH e que o aumento de sua expressão permitiu maior regeneração de NADPH, tendo efeito positivo na síntese das moléculas dependentes de NADPH testadas, o que esta de acordo com o papel geralmente atribuído a transidrogenase ligada a membrana (AHMAD; GLAVAS; BRAGG, 1992; ANDERLUND et al., 1999; BRAGG, 1998; HOEK; RYDSTROM, 1988; MEULLER et al., 2001; SAUER et al., 2004; VOORDOUW; VIES; THEMMEN, 1983).

Estudos feitos especificamente no efeito da modificação do nível de transcrição do gene udhA na produção de moléculas que dependem de NADPH para sua síntese também podem ser citados, como o trabalho de Sánchez et al. e o de Fu et al.

O trabalho de Sánchez et al. de 2006 estudou a utilidade da manipulação do nível de NADPH, usando como base o efeito da maior quantidade de NADPH na produção de $\mathrm{P} 3 \mathrm{HB}$ em uma $E$. coli recombinante. O trabalho focou na disponibilidade de NADPH devido a grande quantidade de compostos de interesse industrial que dependem do cofator NADPH para sua síntese em microrganismos, sendo P3HB um desses compostos. Acetoacetil-CoA redutase, a segunda das três enzimas da rota de conversão de acetil-CoA para P3HB, precisa de NADPH, como anteriormente discutido.

Para aumentar a quantidade de NADPH na célula, foi feita a super-expressão do gene udhA (que codifica a enzima transidrogenase solúvel), em E. coli recombinante expressando o operon de síntese de P3HB da Alcaligenes eutrophus. A participação da transidrogenase udhA na produção de P3HB segundo o artigo, esta ilustrada na Figura 11.

Figura 11 - Ciclo do NADPH por ação da transidrogenase UdhA na produção de PHB na Escherichia coli

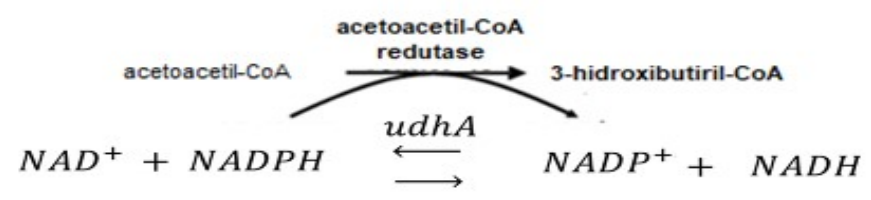


Foi realizado cultivo em frasco com meio LB por 31 horas, em condições aeróbias, após as cepas receberem o operon de síntese de P3HB por expressão de plasmídio. Em todos os ensaios em que a produção de $\mathrm{P} 3 \mathrm{HB}$ foi calculada, a superexpressão do gene udhA resultou em aumento considerável da produção de $\mathrm{P} 3 \mathrm{HB}$. A super-expressão do gene $u d h A$ elevou a porcentagem de P3HB em massa seca de célula, de 49 para $66 \%$ e a concentração final aumentou de 3,52 g/L para 6,42 $\mathrm{g} / \mathrm{L}$ de P3HB. A massa total de célula seca por litro também foi maior na cepa com super-expressão do gene $u d h A$ ao final do cultivo, tendo concentração de 9,8 g/L contra 7,2 g/L da cepa controle (SANCHEZ et al., 2006).

$\mathrm{O}$ artigo publicado por $\mathrm{Fu}$ et al. em 2014 utilizou estratégias como superexpressão de genes para aumentar a produção de P3HB em Halomonas sp. recombinante. A Halomonas sp. é mais uma das bactérias que possuem as duas isoformas de transidrogenase. Uma dessas estratégias testadas foi a superexpressão do gene udhA. A cepa com super-expressão do gene udhA apresentou um aumento de massa seca de célula de $10 \mathrm{~g} / \mathrm{L}$ para $12 \mathrm{~g} / \mathrm{L}$, aumento do acúmulo de $\mathrm{P} 3 \mathrm{HB}$ de $87 \%$ para $92 \%$ e aumento de da conversão de glicose para $\mathrm{P} 3 \mathrm{HB}$ de $30 \%$ para $42 \%$, se comparada com a cepa sem super-expressão do gene $u d h A$, no cultivo em frasco (FU et al., 2014).

Estes dois trabalhos obtiveram resultados peculiares, pois como apontado anteriormente, em geral acredita-se que a transidrogenase solúvel (codificada pelo gene $u d h A$ ) catalisa a transferência de íons hidreto na direção de consumo de NADPH e geração de NADH. Mas estes resultados sugerem então que, num cenário onde há grande demanda de NADPH, como por exemplo, quando há produção de moléculas que utilizam NADPH na sua rota de síntese, a enzima transidrogenase solúvel, irá catalisar a transferência de íons hidreto no sentido de regeneração de NADPH.

Podem ser citados também, trabalhos que testaram modificação tanto no operon pntAB e no gene udhA, como o de Jan et al. e o de Zheng et al., para avaliar o efeito na produção de moléculas dependentes de NADPH e identificar quais modificações são mais benéficas.

O artigo publicado por Jan et al. em 2013, estudou os efeitos das enzimas PntAB e UdhA, na disponibilidade de NADPH na E. coli MG1655. O produto que foi usado como modelo para estudar o efeito da disponibilidade de NADPH foi o (S)-2cloropropionato, visto que uma das enzimas da rota sintética requer NADPH como 
cofator. Para realizar o estudo, testes foram feito com células que tiveram: operon pntAB deletado, gene udhA deletado, operon pntAB e gene udhA deletados, pntAB super-expresso, $u d h A$ super-expresso, pntAB deletado e $u d h A$ super-expresso, e o tipo selvagem como controle. Todas foram testadas em cultivo em frasco agitado em meio M9, sob condições aeróbias e anaeróbias. Os resultados obtidos estão apresentados na Tabela 1.

Tabela 1 - Fator de conversão obtido nos ensaios em frasco agitado.

\begin{tabular}{|c|c|c|}
\hline Linhagem & $\begin{array}{c}\text { Conversão para cultivo em } \\
\text { condição aeróbia } \\
\left(\frac{\text { mol (S)-2-cloropropionato }}{\text { mol glicose }}\right)\end{array}$ & $\begin{array}{c}\text { Conversão para cultivo em } \\
\text { condição anaeróbia } \\
\left(\frac{\text { mol (S)-2-cloropropionato }}{\text { mol glicose }}\right)\end{array}$ \\
\hline $\begin{array}{c}\text { E. coli MG } 1655 \\
\text { selvagem (controle) }\end{array}$ & 0,58 & 0,58 \\
\hline $\begin{array}{l}\text { E. coli MG } 1655 \text { com } \\
\text { pnt } A B \text { deletado }\end{array}$ & 1,25 & 1,05 \\
\hline $\begin{array}{l}\text { E. coli MG } 1655 \text { com } \\
\text { udhA deletado }\end{array}$ & 0,72 & 0,42 \\
\hline $\begin{array}{l}\text { E. coli MG } 1655 \text { com } \\
\text { pntAB deletado e } \\
\text { udhA deletado }\end{array}$ & 0,81 & 0,78 \\
\hline $\begin{array}{l}\text { E. coli MG } 1655 \text { com } \\
\text { pntAB super-expresso }\end{array}$ & 0,5 & 0,38 \\
\hline $\begin{array}{l}\text { E. coli MG } 1655 \text { com } \\
\text { udhA super-expresso }\end{array}$ & 0,88 & 0,61 \\
\hline $\begin{array}{l}\text { E. coli MG } 1655 \text { com } \\
\text { pntAB deletado e } \\
\text { udhA super-expresso }\end{array}$ & 1,42 & 1,00 \\
\hline
\end{tabular}

Fonte: Adaptado de Jan et al. (2013)

A Tabela 1 indica que as cepas com pntAB deletado, e as com pntAB deletado e $u d h A$ super-expresso tiveram produção conversão maior que a tipo selvagem. A cepa com pntAB deletado teve, aproximadamente, conversão $115 \%$ e $81 \%$ maior que o controle, e a com pntAB deletado e $u d h A$ super-expresso apresentou conversão aproximadamente $145 \%$ e $72 \%$ maior que o controle, para condição aeróbia e anaeróbia respectivamente. O artigo conclui que a presença da 
transidrogenase UdhA tende a regeneração de NADPH em cenário onde há grande necessidade de consumo de NADPH no metabolismo, o que beneficia a produção de compostos dependentes de NADPH como o (S)-2-cloropropionato, enquanto que a presença da transidrogenase PntAB tem o efeito contrário (JAN et al., 2013), resultado que vai na contramão ao que, em geral, se sabe sobre o papel dessas enzimas (HAVERKORN VAN RIJSEWIJK et al., 2016; JAN et al., 2013; SAUER et al., 2004).

Já o trabalho publicado em 2017 por Zheng et al., fez uso de análise de fluxo de uma rede metabólica em escala genômica da $E$. coli, apontando que a introdução da rota não oxidativa de glicólise (no Inglês non-oxidative glycolysis, abreviada como NOG) pode aumentar conversão teórica de P3HB de 0,48 g P3HB/g glicose para $0,64 \mathrm{~g} \mathrm{P} 3 \mathrm{HB} / \mathrm{g}$ glicose. Dado os resultados desta análise, eles construíram uma cepa de E. coli com a rota NOG ampliada. Esta cepa apresentou um aumento de produção de $\mathrm{P} 3 \mathrm{HB}$ de $50 \%$ em relação à cepa de controle. Com o intuito de elevar a produção de $\mathrm{P} 3 \mathrm{HB}$ ainda mais, o aumento da quantidade de NADPH disponível através da super-expressão do pntAB ou udhA foi testado. Os resultados obtidos, em contraste com os indicados pelo trabalho de Jan et al., apontaram que a superexpressão do pntAB na cepa com a rota NOG gerou maior produção do que a com super-expressão de $u d h A$. $O$ artigo não apontou especificamente qual foi a conversão obtida pela cepa com super-expressão do gene $u d h A$, mas indicou que a cepa com super-expressão do pntAB obteve aumento de $12 \%$ do acúmulo de P3HB em relação a cepa com NOG mas sem super-expressão do pntAB (controle). A conversão aumentou de 0,24 g P3HB/g glicose para 0,29 g P3HB/g glicose (ZHENG et al., 2017).

Em suma, embora todas essas informações estejam disponíveis sobre o efeito das enzimas transidrogenase na quantidade de NADPH disponível em E. coli e efeitos na produção de $\mathrm{P} 3 \mathrm{HB}$, ainda não há um consenso na literatura sobre o papel desempenhado por essas enzimas no metabolismo da E. coli, nem quais modificações levariam a maior produtividade de P3HB (HAVERKORN VAN RIJSEWIJK et al., 2016; JAN et al., 2013; SAUER et al., 2004). Por esse motivo, há a necessidade de mais estudos relacionados com modificações do operon pntAB e gene $u d h A$ na produção de $\mathrm{P} 3 \mathrm{HB}$ em E. coli recombinante. 


\section{MATERIAIS E MÉTODOS}

\subsection{Cepas e plasmídios utilizados}

As cepas e plasmídios utilizados para os experimentos em frasco agitado e em biorreator estão descritas no Quadro 1.

Quadro 1- Cepas e plasmídios usados

\begin{tabular}{|l|l|l|}
\hline Linhagem & Características & Origem/Referência \\
\hline MG1655 & $\begin{array}{l}\text { E. coli MG1655 transformada com o } \\
\text { plasmídio pBBR1MCS-2::phaCAB } \\
\text { da R. eutropha }\end{array}$ & $\begin{array}{l}\text { Instituto de Ciências } \\
\text { Biomédicas, laboratório } \\
172\end{array}$ \\
\hline MG1655 $\triangle$ pntAB & $\begin{array}{l}\text { E. coli MG1655 transformada com o } \\
\text { plasmídio pBBR1MCS-2::phaCAB } \\
\text { da } R \text {. eutropha e com deleção do } \\
\text { operon pntAB }\end{array}$ & $\begin{array}{l}\text { Instituto de Ciências } \\
\text { Biomédicas, laboratório } \\
172\end{array}$ \\
\hline MG1655 $\Delta u d h A$ & $\begin{array}{l}\text { E. coli MG1655 transformada com o } \\
\text { plasmídio pBBR1MCS-2::phaCAB } \\
\text { da } R \text {. eutropha e com deleção do } \\
\text { gene udhA }\end{array}$ & $\begin{array}{l}\text { Instituto de Ciências } \\
\text { Biomédicas, laboratório } \\
172\end{array}$ \\
\hline
\end{tabular}

Fonte: Autoria própria (2019)

\subsection{Meios de cultura}

Os meios de cultura utilizados foram LB (líquido e sólido) e meio mineral, suplementados com o antibiótico canamicina para preservação do plasmídio com o operon de síntese de P3HB nas bactérias ao longo do cultivo. A composição do meio LB líquido é descrita na Tabela 2. O LB sólido possui a mesma composição do líquido, acrescido de $20 \mathrm{~g} / \mathrm{L}$ de ágar.

Tabela 2 - Composição do meio LB líquido

\begin{tabular}{cc}
\hline Composto & Concentração final \\
\hline triptona & $10 \mathrm{~g} / \mathrm{L}$ \\
extrato de levedura & $5 \mathrm{~g} / \mathrm{L}$ \\
$\mathrm{NaCl}$ & $5 \mathrm{~g} / \mathrm{L}$ \\
canamicina & $0,05 \mathrm{~g} / \mathrm{L}$ \\
\hline
\end{tabular}

Fonte: SAMBROOK, FRITSCH e MANIATIS (1989) 
A composição do meio mineral usado nos ensaios em frasco agitado é apresentada na Tabela 3. Nos experimentos em frasco agitado foi testado também o crescimento em meio mineral com adição de $\mathrm{NaCl}$ na concentração final de $4 \mathrm{~g} / \mathrm{L}$. Além dos compostos descritos na tabela 3 , o meio mineral recebe também $1 \mathrm{~mL} / \mathrm{L}$ de solução traços, cuja composição é descrita na Tabela 4.

Tabela 3 - Composição do meio mineral

\begin{tabular}{|c|c|}
\hline Composto & Concentração \\
\hline $\mathrm{Na}_{2} \mathrm{HPO}_{4}$ & $3,5 \mathrm{~g} / \mathrm{L}$ \\
\hline $\mathrm{KH}_{2} \mathrm{PO}_{4}$ & $1,5 \mathrm{~g} / \mathrm{L}$ \\
\hline$\left(\mathrm{NH}_{4}\right)_{2} \mathrm{SO}_{4}$ & $1,0 \mathrm{~g} / \mathrm{L}$ \\
\hline citr. Fe. $\mathrm{NH}_{4}$ & $0,06 \mathrm{~g} / \mathrm{L}$ \\
\hline $\mathrm{MgSO}_{4} .7 \mathrm{H}_{2} \mathrm{O}$ & $0,20 \mathrm{~g} / \mathrm{L}$ \\
\hline $\mathrm{CaCl}_{2} \cdot 2 \mathrm{H}_{2} \mathrm{O}$ & $0,01 \mathrm{~g} / \mathrm{L}$ \\
\hline canamicina & $0,05 \mathrm{~g} / \mathrm{L}$ \\
\hline
\end{tabular}

Fonte: RAMSAY et al. (1990)

Tabela 4 - Composição da solução elementos traços

\begin{tabular}{cc}
\hline Compostos & Concentração \\
\hline $\mathrm{CuSO}_{4} \cdot 5 \mathrm{H}_{2} \mathrm{O}$ & $0,01 \mathrm{~g} / \mathrm{L}$ \\
$\mathrm{NiCl}_{2} 6 \mathrm{H}_{2} \mathrm{O}$ & $0,02 \mathrm{~g} / \mathrm{L}$ \\
$\mathrm{NaMoO}_{4} \cdot 2 \mathrm{H}_{2} \mathrm{O}$ & $0,03 \mathrm{~g} / \mathrm{L}$ \\
$\mathrm{H}_{3} \mathrm{BO}_{3}$ & $0,30 \mathrm{~g} / \mathrm{L}$ \\
$\mathrm{CoCl}_{2} \cdot 6 \mathrm{H}_{2} \mathrm{O}$ & $0,20 \mathrm{~g} / \mathrm{L}$ \\
$\mathrm{ZnSO}_{4} \cdot 7 \mathrm{H}_{2} \mathrm{O}$ & $0,10 \mathrm{~g} / \mathrm{L}$ \\
$\mathrm{MnCl}_{2} \cdot 4 \mathrm{H}_{2} \mathrm{O}$ & $0,03 \mathrm{~g} / \mathrm{L}$ \\
\hline
\end{tabular}

Fonte: RAMSAY et al.(1990)

Os experimentos em biorreator utilizaram o meio mineral com composição descrita na Tabela 5 , além de $2 \mathrm{~mL} / \mathrm{L}$ de solução elementos traços com composição conforme indicada na Tabela 4. 
Tabela 5 - Composição do meio utilizado nos experimentos em biorreator

\begin{tabular}{cc}
\hline Composto & Concentração \\
\hline $\mathrm{NaCl}$ & $4 \mathrm{~g} / \mathrm{L}$ \\
$\mathrm{KH}_{2} \mathrm{PO}_{4}$ & $0,5 \mathrm{~g} / \mathrm{L}$ \\
$\left(\mathrm{NH}_{4}\right)_{2} \mathrm{SO}_{4}$ & $1,0 \mathrm{~g} / \mathrm{L}$ \\
citr. $\mathrm{Fe}_{4} \mathrm{NH}_{4}$ & $0,06 \mathrm{~g} / \mathrm{L}$ \\
$\mathrm{MgSO}_{4} .7 \mathrm{H}_{2} \mathrm{O}$ & $0,2 \mathrm{~g} / \mathrm{L}$ \\
$\mathrm{CaCl}_{2} .2 \mathrm{H}_{2} \mathrm{O}$ & $0,01 \mathrm{~g} / \mathrm{L}$ \\
canamicina & $0,05 \mathrm{~g} / \mathrm{L}$ \\
\hline
\end{tabular}

Fonte: Autoria própria (2019)

\subsection{Experimentos em frasco}

Cultivo em frasco agitado com as três linhagens descritas no Quadro 1 foi realizado em meio mineral sem e com suplementação de $\mathrm{NaCl}$ (concentração de 4 g/L). O crescimento celular, concentração de glicose, teor de P3HB (\% massa de célula total) e a concentração de P3HB foram analisados

\subsubsection{Pré-inóculo para experimento em frasco}

Culturas de E. coli MG1655 selvagem, E. coli MG1655 com operon pntAB deletado e E. coli MG1655 com gene udhA deletado, estocadas em congelador a $80{ }^{\circ} \mathrm{C}$ foram estriadas em placas com LBK (LB suplementado com canamicina) sólido e cultivadas por 24 horas em estufa a $37^{\circ} \mathrm{C}$. Colônias isoladas, obtidas destas placas, foram utilizadas para inocular meio LBK líquido. Cultivo em $25 \mathrm{~mL}$ de LBK foi realizado durante 24 horas em agitador mecânico a $37^{\circ} \mathrm{C}$ e $150 \mathrm{RPM}$.

\subsubsection{Inóculo para experimento em frasco}

Volume de $2,5 \mathrm{~mL}$ do cultivo em LBK, foi utilizado para inocular o meio mineral. Foram adicionados também, $5 \mathrm{~mL}$ de uma solução $75 \mathrm{~g} / \mathrm{L}$ de glicose e 25 $\mu \mathrm{L}$ de canamicina $50 \mathrm{~g} / \mathrm{L}$, resultando numa solução final com volume de $25 \mathrm{~mL}$, e concentração de $15 \mathrm{~g} / \mathrm{L}$ de glicose, que foi cultivada em agitador mecânico por 48 horas a $37^{\circ} \mathrm{C}$ e $150 \mathrm{rpm}$. Amostras de $10 \mathrm{~mL}$ foram retiradas do meio mineral após inoculação, e depois a cada 24 horas. 


\subsection{Experimentos em biorreator}

Concluído os cultivos em frasco agitado, cultivo das cepas selvagem, $\triangle p n t A B$ e $\triangle u d h A$ em meio mineral suplementado com $\mathrm{NaCl}(4 / L)$ foi realizado em biorreator.

\subsubsection{Pré-inóculo para experimento em biorreator}

Culturas das cepas de E. coli, estocadas em congelador a $-80{ }^{\circ} \mathrm{C}$ foram estriadas em placas com LBK sólido e cultivadas por 24 horas em estufa a $37^{\circ} \mathrm{C}$. Colônias isoladas, obtidas destas placas, foram utilizadas para inocular o meio LBK líquido. Cultivo em $20 \mathrm{~mL}$ de LBK foi feito durante 12 horas em agitador mecânico a $37^{\circ} \mathrm{C}$ e 150 RPM.

\subsubsection{Inóculo para experimento em biorreator}

Todo o volume do cultivo em LBK, $20 \mathrm{~mL}$ de uma solução $200 \mathrm{~g} / \mathrm{L}$ de glicose e $200 \mu \mathrm{L}$ de canamicina foram adicionados ao meio mineral resultando numa solução final com volume total de $200 \mathrm{~mL}$ e concentração de glicose de $20 \mathrm{~g} / \mathrm{L}$, que foi cultivada em agitador mecânico por 16 horas a $37^{\circ} \mathrm{C}$ e $150 \mathrm{rpm}$. Após o cultivo, este meio contendo as células foi utilizado para inocular o biorreator.

\subsubsection{Procedimento e condições de cultivo em biorreator}

Reatores da marca INFORS HT, com 1,72 litros de meio mineral foram autoclavados por 1 hora a $127{ }^{\circ} \mathrm{C}$ e $1 \mathrm{kgf} / \mathrm{cm}^{2}$ (manométrica). Volume de $80 \mathrm{~mL}$ de uma solução concentrada de glicose (500 g/L) previamente autoclavada, e $2 \mathrm{~mL}$ de canamicina previamente filtrada foram adicionados, e em seguida, a inoculação com $200 \mathrm{~mL}$ de cultura em meio mineral foi feita, alcançando um volume final de meio de 2 litros. A concentração de glicose inicial no reator foi de aproximadamente $20 \mathrm{~g} / \mathrm{L}$, e adição de mais glicose ao longo do cultivo foi feito através da injeção de pulsos de $20 \mathrm{~mL}$ de glicose ( $500 \mathrm{~g} / \mathrm{L})$, uma vez a cada 12 horas aproximadamente, até totalizar três adições. $\mathrm{O}$ cultivo foi realizado com controle de temperatura $\left(37^{\circ} \mathrm{C}\right), \mathrm{pH}(7)$, e agitação (300 rpm), e a vazão de ar alimentada foi de $1 \mathrm{~L} / \mathrm{min}$. Amostras de $10 \mathrm{~mL}$ 
foram retiradas a cada uma hora e trinta minutos, durante as primeiras $24 \mathrm{~h}$ de cultivo, e em sequência, a cada duas horas até o final do cultivo (aproximadamente 40 horas), e os valores de $\mathrm{pH}, \mathrm{pO}_{2}$, e temperatura foram registrados. Centrifuga da marca Hitachi CR21GIII foi utilizada para separar as células do meio. As amostras foram centrifugadas em $10000 \times \mathrm{g}$ por $10 \mathrm{~min}$. O meio sobrenadante foi transferido para cubos cônicos, e as células para microtubos, e então congeladas a $-20{ }^{\circ} \mathrm{C}$, para posterior análise. Plaqueamento em LB sólido foi realizado ao fim do cultivo para controle de contaminação por inspeção das colônias formadas.

\subsection{Dosagem de glicose e ácidos}

Para análise da glicose e ácidos, as amostras de meio foram filtradas com filtro de $0,22 \mu \mathrm{m}$ para retirada de partículas que podem causar dano ao HPLC, e transferidas para frascos vial, para injeção no HPLC, modelo UltiMate 3000 da companhia Thermo Fisher Scientific (Dionex, Sunnyvale, CA, Estados Unidos), com coluna Aminex HPX-87H (Bio-Rad, Hercules, CA, Estados Unidos) a $40{ }^{\circ} \mathrm{C}$ e detector por índice de refração (Shodex, Kawasaki, Kanagawa, Japão) a $40{ }^{\circ} \mathrm{C} . \mathrm{O}$ volume de injeção de amostra foi de $10 \mu \mathrm{L}$, e a fase móvel utilizada foi $\mathrm{H}_{2} \mathrm{SO}_{4} 5 \mathrm{mM}$ com vazão de $0,6 \mathrm{~mL} / \mathrm{min}$ (BOCANEGRA, 2012).

\subsection{Massa seca de célula}

Os microtubos com as células foram liofilizados com o liofilizador da marca LABCONCO, para retirada de umidade. Os pellets foram pesados em balança analítica para quantificação da massa seca de célula de cada amostra.

\subsection{Propanólise}

Após medida da massa seca de célula, pellets de célula de até $15 \mathrm{mg}$ foram transferidos para tubos apropriados, e $100 \mu \mathrm{L}$ de ácido benzóico $(40 \mathrm{~g} / \mathrm{L}$ de propanol) foram adicionados como solução padrão. Foram adicionados também, 2 $\mathrm{mL}$ de solução de n-propanol e ácido clorídrico (proporção 4:1 na solução, respectivamente) e $2 \mathrm{~mL}$ de 1,2-dicloroetano. Os tubos com os reagentes foram agitados e colocados em banho-maria na água fervente, durante 30 minutos. 
Terminada esta etapa, os tubos foram novamente agitados e colocados em banhomaria, por 2 horas e 30 minutos. Em sequência, $4 \mathrm{~mL}$ de água destilada foram adicionadas, e agitação em vortex foi realizada, seguida de separação das fases aquosa e orgânica. A fase aquosa foi descartada e a fase orgânica foi transferida para vials, para injeção em cromatógrafo gasoso (CG) 7683B series (Agilent Technologies, Santa Clara, CA, Estados Unidos), com coluna HP-5 (5\% fenilmetilsiloxano, comprimento de $30 \mathrm{~m}$, diâmetro de $0,25 \mathrm{~mm}$ e espessura de filme de $0,25 \mu \mathrm{m}$ ) para análise de 3-hidroxialcanoatos propil-ésteres, obtendo assim o teor de P3HB (\% em massa) contido nas amostras (RIIS; MAI, 1988). O gás de arraste utilizado foi Hélio, na vazão de $0,8 \mathrm{~mL} / \mathrm{min}$, a temperatura de operação do injetor foi de $250{ }^{\circ} \mathrm{C}$, o sistema de deteç̧ão usado foi o de ionização de chama (FID) e o detector trabalhou a $300{ }^{\circ} \mathrm{C}$. O forno trabalhou a $100{ }^{\circ} \mathrm{C}$ por 1 minuto, seguido por aumento programado de temperatura $\left(8^{\circ} \mathrm{C} / \mathrm{min}\right)$ até os $210^{\circ} \mathrm{C}$, onde permaneceu por 15 minutos. 


\section{RESULTADOS E DISCUSSÃO}

\subsection{Cultivos em frasco agitado}

Os cultivos em frasco agitado foram realizados em meio mineral com glicose (15 g/L) como fonte de carbono, e suplementado ou não com $\mathrm{NaCl}$ (4 g/L), visto que alguns trabalhos indicam que a suplementação de baixas concentrações de $\mathrm{NaCl}$ podem ser benéficas ao acúmulo de PHAs (PASSANHA et al., 2014) e ao crescimento da E. coli (ABDULKARIM; FATIMAH; ANDERSON, 2009). Nessa etapa, foram avaliadas as seguintes cepas: E. coli MG1655, referenciada como "selvagem", e os mutantes derivados da cepa E. coli MG1655 com as deleções no gene udhA e no operon pnt $A B$, referenciadas como $\triangle u d h A$ e $\triangle p n t A B$, respectivamente. As Figuras 12, 13 e 14, apresentam a concentração de células total (biomassa celular mais a massa de polímeros acumulada pela mesma), o teor de P3HB expresso em porcentagem da massa total, a concentração de P3HB, e a concentração de células residual (que engloba a biomassa celular apenas), a concentração de glicose no meio, e a concentração de ácidos produzidos, em função do tempo.

Os dados presentes no gráfico de concentração de células residual da Figura 12, apontam que a cepa $\Delta u d h A$ apresentou menor crescimento celular, tanto no cultivo em meio mineral sem $\mathrm{NaCl}$, como no cultivo em meio mineral suplementado com $\mathrm{NaCl}$, atingindo ao final do cultivo concentrações inferiores a $0,5 \mathrm{~g} / \mathrm{L}$ de biomassa residual. Já o crescimento da linhagem selvagem e da $\triangle p n t A B$ foi semelhante em ambas as condições de cultivo, atingindo valores na faixa de 1 - 1,5 $\mathrm{g} / \mathrm{L}$ de biomassa residual. Todas as três cepas obtiveram biomassa residual superior no meio suplementado com $\mathrm{NaCl}$, mas a diferença foi mais pronunciada na cepa selvagem. Conforme mencionado na revisão bibliográfica, o trabalho publicado em 2018 por ZHAO et al., indicou que a $E$. coli com deleção do gene $u d h A$ apresentou crescimento inferior a cepa controle no crescimento em meio ácido ( $\mathrm{pH}$ de 4,9) com acetato como fonte de carbono (que no metabolismo da E. coli leva a excesso de NADPH) em meio de cultura mínimo, dado a baixa quantidade de NADH disponível como efeito da ausência da transidrogenase UdhA, visto que a quantidade de NADH disponível teve influência no nível de expressão de seis genes relacionados a um dos sistemas de resistência a ambientes ácidos da E. coli. Embora o meio de cultura e fonte de carbono sejam diferentes, uma hipótese para o crescimento inferior da 
cepa $\Delta u d h A$, é então a relatada resistência inferior a meios ácidos (ZHAO et al., 2018), visto que não houve controle de $\mathrm{pH}$ (chegando assim a pHs de aproximadamente 5 , ao final do cultivo).

Figura 12 - Cultivo em frasco agitado em meio mineral suplementado ou não com $\mathrm{NaCl}(4 \mathrm{~g} / \mathrm{L})$
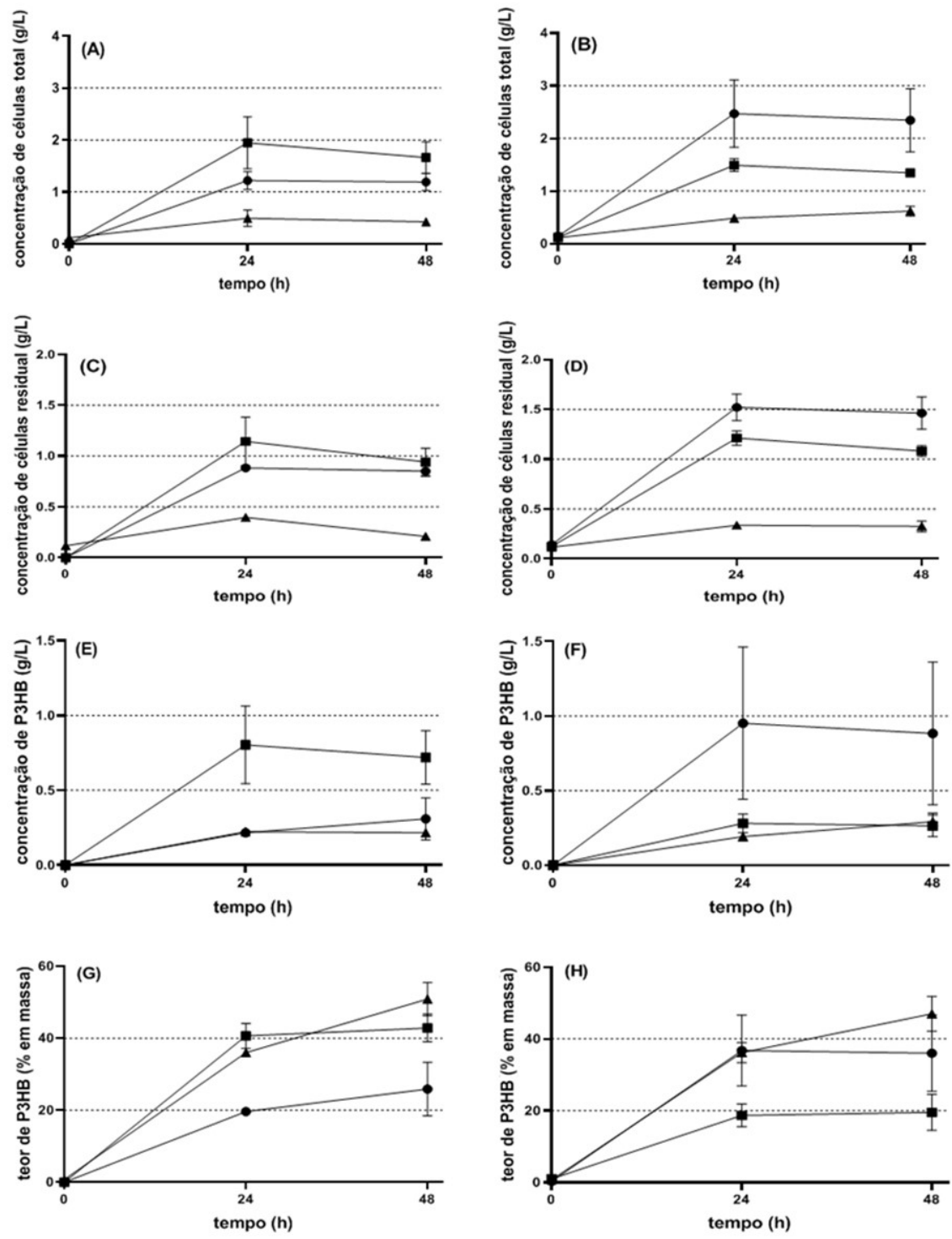

Concentração de células total em meio sem $(A)$ e com $\mathrm{NaCl}(B)$, concentração de células residual em meio sem (C) e com $\mathrm{NaCl}(D)$, concentração de P3HB em meio sem (E) e com $\mathrm{NaCl}(F)$ e teor de

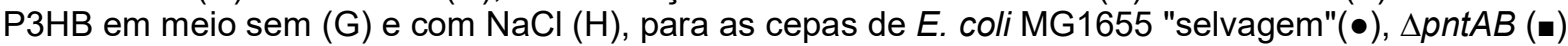
e $\triangle u d h A(\mathbf{\Delta})$ expressando o plasmídio pBBR2::phaCAB 
No que diz respeito a produção de $\mathrm{P} 3 \mathrm{HB}$, a cepa $\Delta u d h A$ foi a que apresentou maior teor de $\mathrm{P} 3 \mathrm{HB}$. Visto que a cepa $\Delta u d h A$ possui apenas a transidrogenase PntAB, que transfere equivalentes redutores do NADH para NADPH, é de se esperar que essa cepa tenha mais NADPH disponível para a reação catalisada pela enzima acetoacetil - CoA redutase, na rota de síntese de P3HB. Mas mesmo sendo a cepa que apresentou o maior teor de P3HB, a concentração final de P3HB obtida por esta cepa foi a menor dentre as três, como consequência do crescimento celular inferior. A cepa $\Delta u d h A$ alcançou uma concentração de P3HB de aproximadamente 0,2 e 0,3 $\mathrm{g} / \mathrm{L}$, para o cultivo sem e com $\mathrm{NaCl}$, respectivamente, valor equivalente ao obtido pelas cepas selvagem e $\triangle p n t A B$ nas suas condições de cultivos menos favoráveis. Nota-se também que a suplementação com $\mathrm{NaCl}$ foi favorável a produção de $\mathrm{P} 3 \mathrm{HB}$ na cepa selvagem mas severamente negativo a produção de $\mathrm{P} 3 \mathrm{HB}$ da cepa $\triangle p n t A B$. Uma possível explicação para o maior produção de $\mathrm{P} 3 \mathrm{HB}$ das cepas $\triangle u d h A$ e selvagem, quando em meio suplementado com $\mathrm{NaCl}$, é o papel secundário dos grânulos de P3HB acumulados como mecanismo de adaptação a meios com osmolaridade superior, conforme descrito na revisão bibliográfica. Logo, as cepas selvagem e $\Delta u d h A$ podem ter utilizado a ação da transidrigenase PntAB para aumentar a quantidade de NADPH disponível e acumular P3HB como mecanismo extra de defesa a osmolaridade levemente superior do meio. Já uma possível explicação para a produção inferior de $\mathrm{P} 3 \mathrm{HB}$ da cepa $\triangle p n t A B$ pode ser a que, dada a impossibilidade de usar a ação da transidrogenase PntAB, a célula recorreu aos outros sistemas de defesa da E. coli a meios de osmolaridade superior. Os artigos de Canovas et al., e Houssin et al., apontam que o transporte de potássio $\left(\mathrm{K}^{+}\right)$e o transporte ou síntese de solutos compatíveis como aminoácidos (glutamato e prolina), poliálcoois (glicerol e trealose) e orgânicos zwitteriônicos (betaínas como a glicocetaina, a crotonobotaina e a carnitina), são também um mecanismo usado pela E. coli e outras bactérias para lidar com meios de alta osmolaridade (CÁNOVAS et al., 2007; HOUSSIN et al., 1991), mas que estes sistemas aumentam a demanda por energia da célula, como indicado pelo aumento de sínteses de ATP a custo da baixa na razão de NADH/NAD+, sob tais circunstâncias (ARENSE et al., 2010; CÁNOVAS et al., 2007; SHABALA et al., 2009). A cepa $\triangle p n t A B$ pode então ter usado a transidrogenase UdhA, para transferir equivalentes redutores do NADPH para $\mathrm{NADH}$, aumentando a quantidade de NADH disponível para uso na síntese de ATP na cadeia de transporte de elétrons. Esta baixa na quantidade de NADPH disponível 
pode explicar a diminuição do acúmulo de $\mathrm{P} 3 \mathrm{HB}$ em meio suplementado com $\mathrm{NaCl}$ sofrido pela cepa $\triangle p n t A B$.

Figura 13 - Concentração de glicose no cultivo em frasco agitado em meio mineral suplementado ou não com $\mathrm{NaCl}$ (4 g/L)
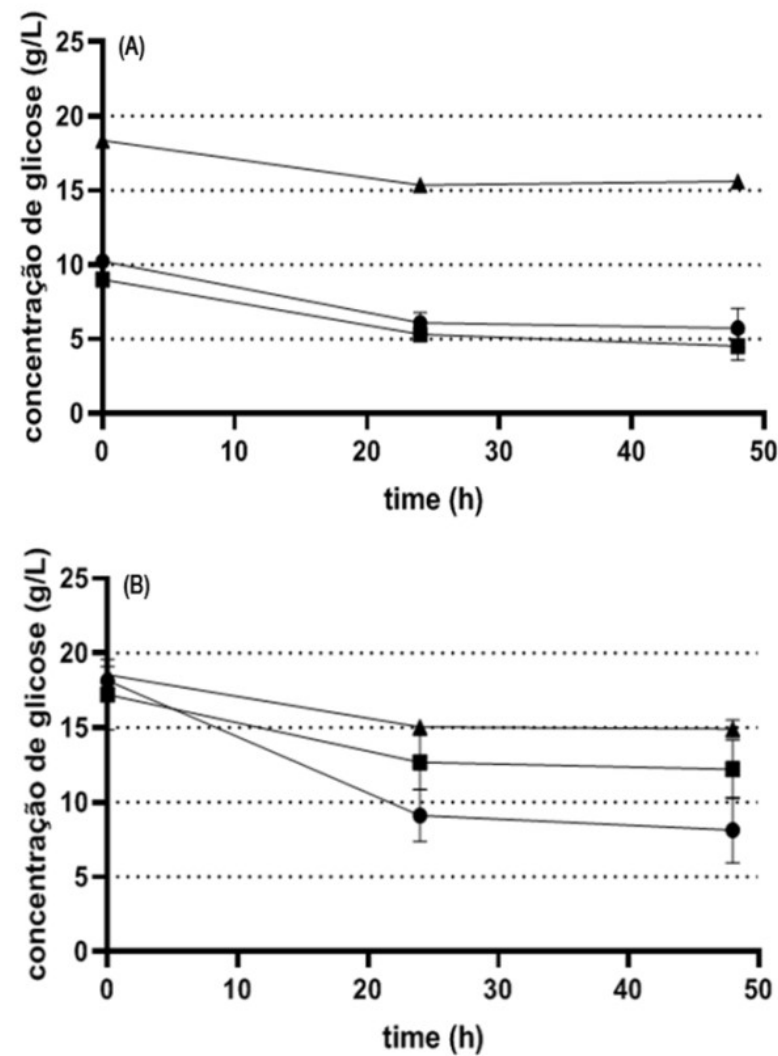

Concentração de glicose em meio sem (A) e com $\mathrm{NaCl}(\mathrm{B})$ para as cepas de E. coli MG1655

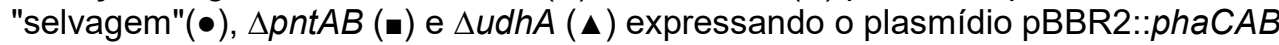

Fonte: Autoria própria (2019)

Com os dados de concentração de P3HB (Figura 12) e glicose (Figura13) ao longo do tempo, o P3HB produzido e a glicose consumida foram calculados, determinado assim, o fator de conversão. A produtividade foi calculada usando os valores de concentração de P3HB (Figura 12) e o tempo discorrido ao final do cultivo. Os valores de fator de conversão e produtividade obtidos para cada cepa estão apresentados nas Tabelas 6 e 7. 
Tabela 6 - Fator de conversão obtido para cada cepa no ensaio em frasco com meio mineral sem suplementação de $\mathrm{NaCl}$

\begin{tabular}{|c|c|c|}
\hline $\begin{array}{c}\text { Cepa } \\
\text { Cultivada }\end{array}$ & $\begin{array}{l}\text { Fator de conversão } \\
\qquad\left(\frac{\mathrm{g} \text { P3HB }}{\text { g glicose }}\right)\end{array}$ & $\begin{array}{l}\text { Produtividade } \\
\qquad\left(\frac{\mathrm{g} \text { P3HB }}{\mathrm{L} \cdot \mathrm{h}}\right)\end{array}$ \\
\hline selvagem & $0,088 \pm 0,0399$ & $0,0073 \pm 0,0036$ \\
\hline$\triangle p n t A B$ & $0,228 \pm 0,0070$ & $0,0150 \pm 0,0040$ \\
\hline$\Delta u d h A$ & 0,213 & $0,0045 \pm 0,0003$ \\
\hline
\end{tabular}

Fonte: Autoria própria (2019)

Tabela 7 - Fator de conversão obtido para cada cepa no ensaio em frasco com meio mineral com suplementação de $\mathrm{NaCl}$

\begin{tabular}{ccc}
\hline $\begin{array}{c}\text { Cepa } \\
\text { Cultivada }\end{array}$ & $\begin{array}{c}\text { Fator de conversão } \\
\left(\frac{\mathrm{g} \text { P3HB }}{\text { g glicose }}\right)\end{array}$ & $\begin{array}{c}\text { Produtividade } \\
\left(\frac{\mathrm{g} \mathrm{P} 3 \mathrm{HB}}{\mathrm{L} . \mathrm{h}}\right)\end{array}$ \\
\hline selvagem & $0,110 \pm 0,0266$ & $0,0184 \pm 0,0100$ \\
$\Delta$ pntAB & $0,046 \pm 0,0004$ & $0,0047 \pm 0,0010$ \\
$\Delta u d h A$ & $0,152 \pm 0,0121$ & $0,0054 \pm 0,0002$ \\
\hline
\end{tabular}

Fonte: Autoria própria (2019)

Estes resultados indicam que a deleção do operon pntAB teve efeito muito positivo no fator de conversão no meio sem suplementação de $\mathrm{NaCl}$, estando de acordo com o que havia sido documentado pelo trabalho de Jan et al. (2013). A deleção do operon pntAB gerou um aumento da conversão de aproximadamente $159 \%$ em relação a cepa selvagem no cultivo sem sal. No trabalho de Jan et al., conforme anteriormente mencionado, cultivo aeróbio e anaeróbio em meio M9 foi realizado com cepas de $E$. coli MG1655 que tiveram: operon pntAB deletado, gene $u d h A$ deletado, operon pnt $A B$ e gene $u d h A$ deletados, pnt $A B$ super-expresso, $u d h A$ super-expresso, pnt $A B$ deletado e $u d h A$ super-expresso, e o tipo selvagem como controle, para avaliar a produção de (S)-2-cloropropionato, biomolécula que assim como o P3HB, possui uma enzima que precisa de NADPH como cofator (2haloacrilato redutase), na sua rota de síntese. Os resultados obtidos por Jan et al., indicaram que a deleção do operon pntAB aumentou em $115 \%$ o fator de conversão (em mols de produto por mols de substrato consumido) no cultivo aeróbio. Mas os 
resultados da Tabela 6 indicam também que, embora a cepa $\triangle p n t A B$ tenha apresentado a maior produtividade dentre as três cepas no cultivo sem adição de $\mathrm{NaCl}$, a cepa selvagem foi a que apresentou a maior produtividade de P3HB no cultivo em meio suplementado com $\mathrm{NaCl}$, bem como a maior produtividade obtida dos ensaios em frasco, em geral. A produção de ácidos no meio sem e com suplementação de $\mathrm{NaCl}$ é apresentado na Figura 14.

Figura 14 - Concentração de ácidos produzidos no cultivo em frasco agitado em meio mineral suplementado ou não com $\mathrm{NaCl}(4 \mathrm{~g} / \mathrm{L})$
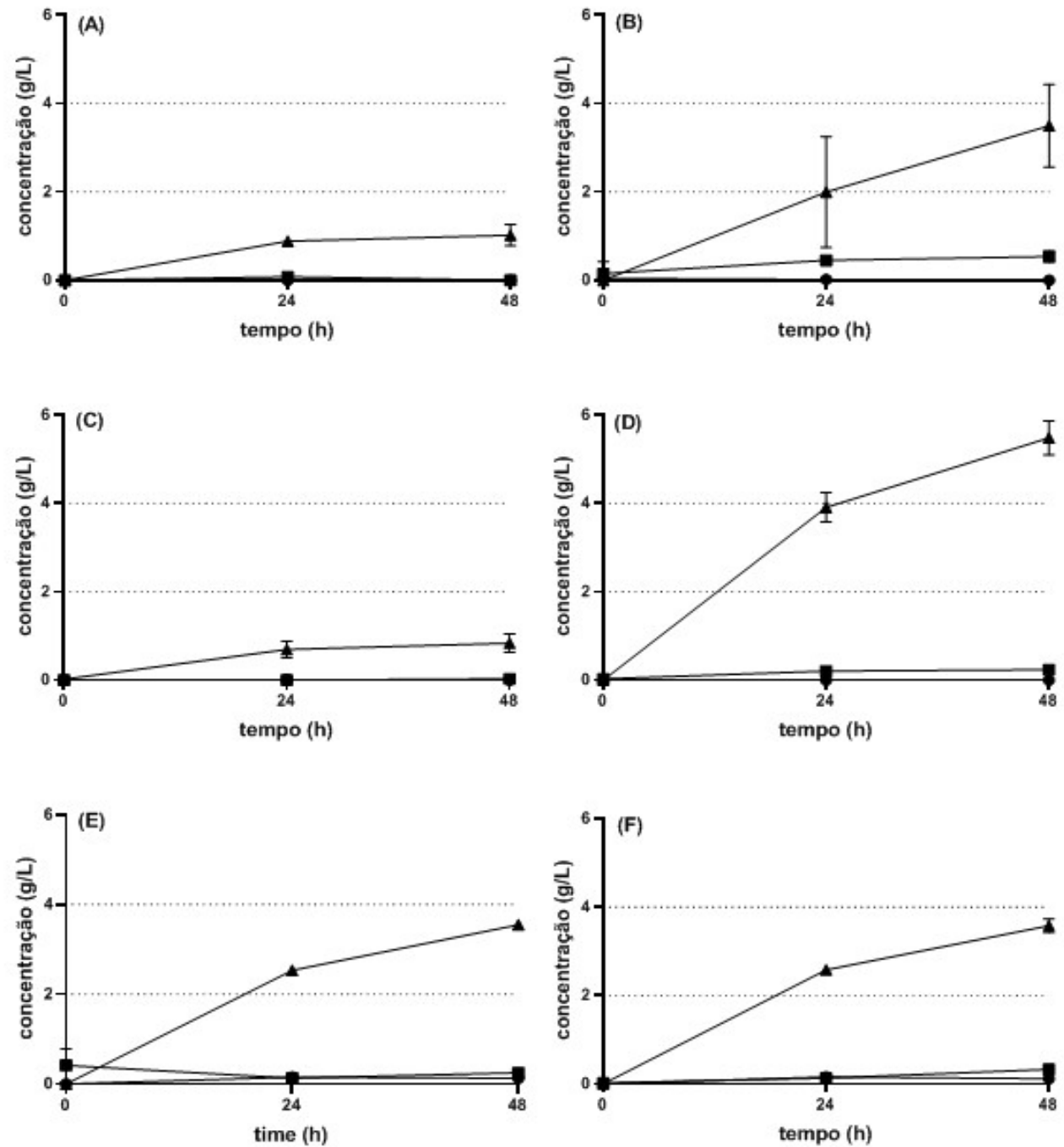

Concentração de lactato $(\bullet)$, formiato $(\boldsymbol{\bullet})$ e acetato $(\boldsymbol{\Delta})$ para a cepa "selvagem" em meio sem $(A)$ e com $\mathrm{NaCl}(\mathrm{B}), \triangle p h t A B$ em meio sem (C) e com $\mathrm{NaCl}(\mathrm{D})$ e $\Delta u d h A$ em meio sem (E) e com $\mathrm{NaCl}(\mathrm{F})$ 


\subsection{Cultivos em biorreator}

Tendo em vista que todas as cepas apresentaram maior crescimento celular no cultivo em meio suplementado com $\mathrm{NaCl}$, os três cultivos em biorreator (sem replicata) foram realizados em meio suplementado com $4 \mathrm{~g} / \mathrm{L}$ de $\mathrm{NaCl}$. A Figura 15 e apresenta a concentração de células total e residual em função do tempo.

Figura 15 - Concentração de células total e residual em função do tempo para cultivo em biorreator em meio suplementado com $\mathrm{NaCl}$
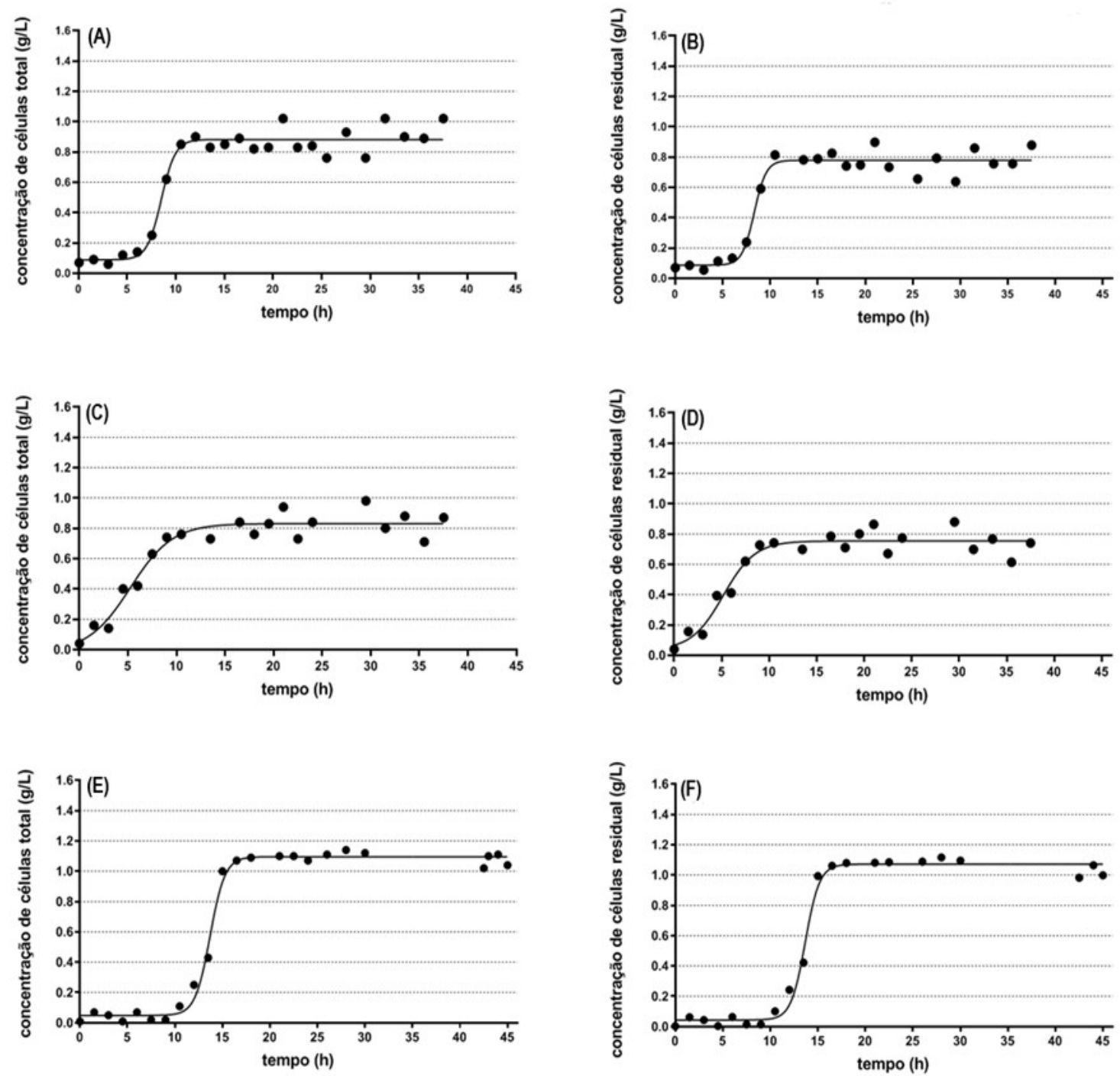

Concentração de células total $(A)$ e residual $(B)$ para a cepa "selvagem", concentração de células total (C) e residual (D) para a cepa $\triangle p n t A B$ e concentração de células total (E) e residual $(F)$ para a cepa $\triangle u d h A$ 
Analisando a cinética de concentração de células residual, nota-se que, como previamente mencionado, a cepa $\Delta u d h A$ não teve crescimento inferior as outras cepas no cultivo em biorreator, diferente do que aconteceu no ensaio em frasco agitado, e muito pelo contrário, acabou apresentando maior massa de célula residual nas condições presentes no biorreator. Já as concentrações de massa de célula residual obtidas nas cepas selvagem e $\triangle p n t A B$ ao final da fase de crescimento exponencial foram próximas, similar ao ocorrido no ensaio em frasco agitado (Figura 12). Além das condições de cultivos diferentes entre os experimentos realizados em frascos agitados e em biorreatores (controle de $\mathrm{pH}$, aeração mais vigorosa, e presença de pulsos de glicose), uma outra hipótese para este maior crescimento é uma possível diferença na concentração de compostos do meio, visto que a preparação e esterilização não foi realizada junto a dos outros dois ensaios (que foram realizados na mesma data), ou seja, um erro de reprodutibilidade. Algo que pode ser também observado é que a cepa $\triangle p n t A B$ não apresentou fase lag significativa, enquanto a cepa $\Delta u d h A$ apresentou uma fase lag extensa, até quase 10 horas de cultivo. A curva de ajuste foi criada com o uso do software GraphPad Prism, usando o modelo sigmoidal, descrita na Equação 3.

$$
f(X)=\text { Base }+\frac{\text { Topo }- \text { Base }}{1+10^{((E C 50-X) * \mu)}}
$$

Sendo:

Base - média dos valores obtidos na fase lag.

Topo - média dos valores obtidos na fase estacionária.

EC50 - O valor no eixo $\mathrm{X}$ correspondente ao ponto no meio da fase exponencial.

$X$ - Valor do tempo, no eixo $\mathrm{x}$.

$\mu-\mathrm{A}$ velocidade específica de crescimento na fase exponencial. 
Figura 16 - Teor e concentração de P3HB em função do tempo para cultivo em biorreator em meio suplementado com $\mathrm{NaCl}$
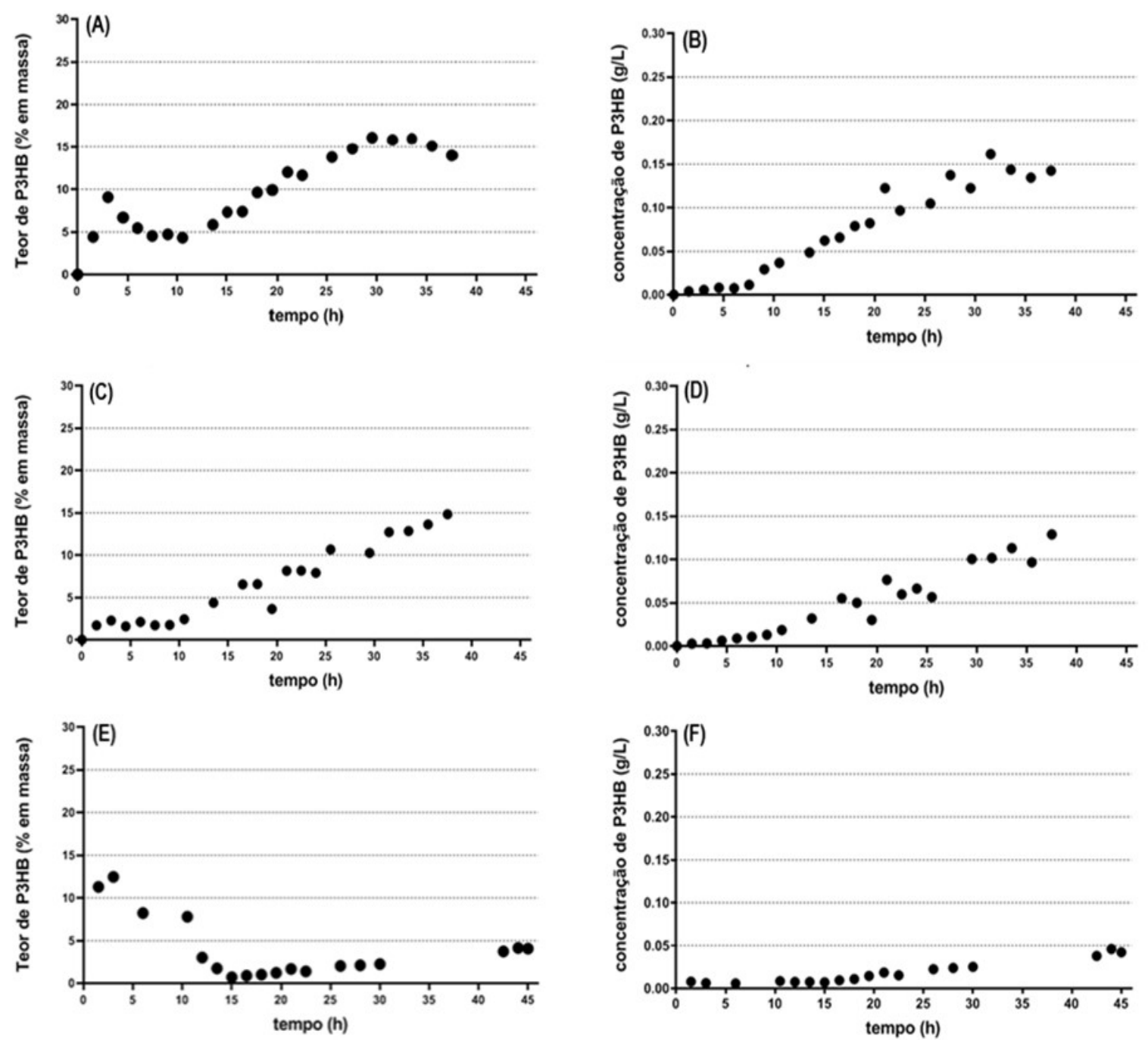

Teor (A) e concentração (B) de P3HB para a cepa "selvagem", teor (C) e concentração (D) de P3HB para a cepa $\triangle p n t A B$ e teor $(E)$ e concentração $(F)$ de $P 3 H B$ para a cepa $\triangle u d h A$

Fonte: Autoria própria (2019)

Os valores altos obtidos para o teor de P3HB no início do cultivo (Figura 15), para as cepas selvagem e $\Delta u d h A$ são provavelmente erros oriundos da dificuldade de manusear e quantificar adequadamente as massas de célula obtidas nas amostragens para a realização da propanólise, visto que durante todo o período de 5 $\mathrm{h}$ de fase lag da cepa selvagem, e $10 \mathrm{~h}$ da cepa $\Delta u d h A$, a concentração de células era muito baixa. A quantificação do teor de P3HB nas primeiras amostragens da cepa $\triangle p n t A B$ não tiveram esse problema, já que com a curta fase lag dessa cepa, a massa de célula obtida em cada amostragem se tornou significativa rapidamente. $O$ 
teor e a concentração de P3HB foram maiores na cepa selvagem do que na cepa $\triangle p n t A B$, embora a diferença seja menor do que havia ocorrido no ensaio em frasco agitado. E surpreendentemente, diferente do ensaio em frasco, a cepa $\Delta u d h A$ foi a que apresentou o menor teor de P3HB entre as demais cepas. O motivo disso não foi esclarecido, mas uma hipótese é a de que pode ter ocorrido perda do plasmídio com o operon de síntese de $\mathrm{P} 3 \mathrm{HB}$ na cepa $\Delta u d h A$ ao longo das gerações em decorrência de algum problema com o antibiótico (perda acentuada ao longo das amostragens e evaporação do meio de cultura, ou inativação). Outra hipótese é que as condições de cultivo no biorreator na presença de sais $(\mathrm{NaCl})$ tenham inibido a produção de P3HB pela cepa $\Delta u d h A$.

De forma geral, o perfil de concentração de P3HB ao longo to tempo de cultivo, indica que o início de produção de $\mathrm{P} 3 \mathrm{HB}$ ocorreu apenas próximo ao termino da fase de crescimento exponencial, para todas as cepas. Devido ao baixo teor de P3HB acumulado pela cepa $\Delta u d h A$, a concentração de $\mathrm{P} 3 \mathrm{HB}$ obtida no cultivo dessa cepa foi a menor dentre os ensaios em biorreator.

A Figura 17 apresenta a concentração de glicose no meio, e a produção de ácidos orgânicos, ao longo do cultivo. Nos ensaios em biorreator, foram adicionados três pulsos de glicose de $20 \mathrm{~mL}$ (com uma solução de $500 \mathrm{~g}$ glicose/L) com o intuito de promover uma limitação por outra fonte nutricional que não a fonte de carbono. $O$ primeiro pulso foi aplicado às 24 horas de cultivo, e os dois pulsos subsequentes foram dados em intervalos de 6 horas, de forma que o último pulso fosse dado às 36 horas de cultivo. A única diferença desses pulsos foi no horário de injeção dos dois primeiros pulsos no cultivo com a cepa $\Delta u d h A$ em relação às outras duas, o que pode explicar o perfil diferente de concentração de glicose no meio das cepas selvagem e $\Delta p n t A B$, em comparação com a cepa $\Delta u d h A$ como mostra a Figura 17. A Figura 17 aponta também que as cepas produziram alguns dos ácidos resultantes da via fermentativa ácida mista, indicando que durante o cultivo em limitação de oxigênio (agitação fixa de 300 rpm e vazão de alimentação de ar de 1 L/min), as cepas realizaram metabolismo anaeróbio (BARBOSA; GOMEZ; TORRES, 2018). A produção de acetato parece ter ocorrido enquanto havia crescimento celular, caindo bruscamente ao final da fase de crescimento exponencial. 
Figura 17 - Concentração de glicose no meio, e a produção de ácidos em função do tempo para cultivo em biorreator em meio suplementado com $\mathrm{NaCl}$
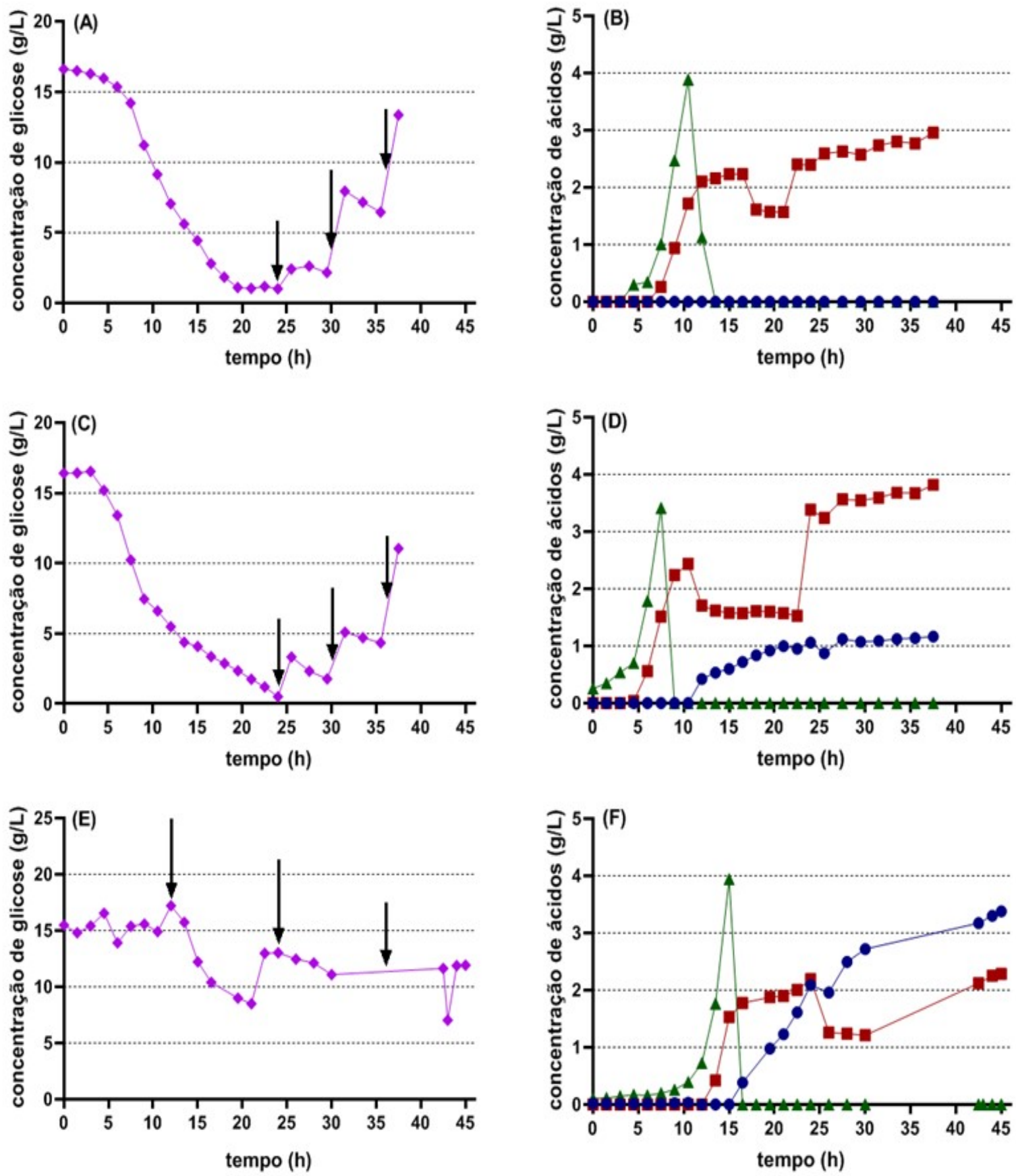

Concentração de glicose para as cepas "selvagem" (A), $\triangle p n t A B(C)$ e $\Delta u d h A$ (E). Setas indicam os horários de adição de pulso de glicose. Concentração de lactato $(\bullet)$, formiato $(\square)$ e acetato $(\Delta)$ para as cepas "selvagem" (B), $\triangle p n t A B(D)$ e $\triangle u d h A(F)$ 
A cepa $\triangle p n t A B$ foi que apresentou maior produção de formiato, enquanto a cepa $\Delta u d h A$ foi a que apresentou a menor produção deste ácido, embora a diferença não seja muito acentuada. Em contrapartida, a produção de lactato variou consideravelmente entre as três cepas. A cepa selvagem não produziu lactato ao longo do cultivo enquanto as duas mutantes produziram na fase de pulsos de glicose. A cepa $\triangle p n t A B$ alcançou valores de $1,2 \mathrm{~g} / \mathrm{L}$ e a cepa $\triangle u d h A$ obteve produção consideravelmente maior, alcançando concentrações de 3,5 g/L. Dessa forma, uma parte considerável da fonte de carbono foi desviada para a produção de lactato nas duas cepas mutantes, o que pode explicar, pelo menos em parte, a menor produção de $\mathrm{P} 3 \mathrm{HB}$ observada nessas duas cepas em relação à cepa selvagem.

Os valores de velocidade específica de crescimento $(\mu)$, fator de conversão (através dos cálculos de P3HB produzido e glicose consumida, usando os dados das Figuras 16 e 17) e produtividade ao final do cultivo (com a concentração de P3HB e tempo de cultivo final da Figura 16) são apresentados na Tabela 8.

Tabela 8 - Velocidade específica de crescimento, fator de conversão e produtividade de P3HB para cultivo em biorreator

\begin{tabular}{cccc}
\hline $\begin{array}{c}\text { Cepa } \\
\text { Cultivada }\end{array}$ & $\begin{array}{c}\mu \\
\left(\mathrm{h}^{-1}\right)\end{array}$ & $\begin{array}{c}\text { Fator de conversão } \\
\left(\frac{\mathrm{g} \text { P3HB }}{\text { g glicose }}\right)\end{array}$ & $\begin{array}{c}\text { Produtividade } \\
\left(\frac{\mathrm{g} \text { P3HB }}{\mathrm{L} \cdot \mathrm{h}}\right)\end{array}$ \\
\hline selvagem & 0,69 & 0,0063 & 0,0043 \\
$\Delta$ pntAB & 0,26 & 0,0049 & 0,0035 \\
$\Delta u d h A$ & 0,58 & 0,0012 & 0,0011 \\
\hline
\end{tabular}

Fonte: Autoria própria (2019)

As velocidades específicas de crescimento foram comparadas com resultados apontados por Sauer et al., que também testou cepas de E. coli MG1655 e mutantes com deleção no operon pntAB ou no gene udhA em cultivos com glicose como fonte de carbono. No trabalho de Sauer o $\mu\left(\mathrm{h}^{-1}\right)$ das cepas selvagem, $\triangle p h t A B$ e $\Delta u d h A$, foram respectivamente, 0,67 $( \pm 0,01), 0,45( \pm 0,05)$, e $0,67( \pm 0,02)$. Nota-se que a cepa selvagem e a $\Delta u d h A$ tiveram $\mu$ muito próximo, enquanto a cepa $\triangle p n t A B$ teve $\mu$ $33 \%$ inferior em relação a selvagem. Em contrapartida, os resultados no presente trabalho (Tabela 8 ) apontam que a cepa $\Delta u d h A$ teve $\mu 15 \%$ menor que a cepa 
selvagem, e a diferença no $\mu$ da cepa $\triangle p n t A B$ em relação a cepa selvagem foi ainda mais drástica, sendo $62 \%$ inferior. É importante frisar que no trabalho de Sauer et al., o cultivo foi realizado em meio M9 e em frasco agitado (SAUER et al., 2004). Analisando também os fatores de conversão obtidos nos experimentos em biorreator, nota-se que a cepa com deleção do operon pntAB apresentou fator de conversão $22 \%$ menor que a cepa selvagem, diferente do experimento em frasco, onde o fator de conversão foi consideravelmente maior, e ainda, o fator de conversão obtido pela cepa com o gene udhA deletado foi aproximadamente $81 \%$ inferior ao da cepa selvagem. Comparando também a produtividade, as cepas $\triangle p n t A B$ e $\triangle u d h A$ obtiveram respectivamente uma produtividade $19 \%$ e $74 \%$ inferior a cepa selvagem. 


\section{CONCLUSÕES}

Cultivo em frasco agitado em meio sem e com $\mathrm{NaCl}$, indicou que a cepa $\triangle p n t A B$ obteve maior fator de conversão que a cepas selvagem e $\Delta u d h A$. Em contrapartida, a cepa selvagem cultivada no meio suplementado com $\mathrm{NaCl}$ foi a que alcançou a maior produtividade obtida nos ensaios em frasco. A cepa $\triangle u d h A$ foi a que apresentou o menor crescimento celular, possivelmente devido a menor resistência a $\mathrm{pH}$ baixos, que ocorreu no experimento em frasco agitado visto que este ensaio não contemplava controle de $\mathrm{pH}$. Já no cultivo em biorreator, onde $\mathrm{pH}$ foi mantido em 7, a cepa $\triangle u d h A$ não teve crescimento celular inferior as cepas selvagem e $\triangle p n t A B$. A cepa selvagem foi a que obteve o melhor desempenho nos ensaios em biorreator. As cepas $\triangle p n t A B$ e $\triangle u d h A$ tiveram velocidade específica de crescimento $62 \%$ e $15 \%$, fator de conversão $22 \%$ e $81 \%$ e produtividade $19 \%$ e $74 \%$ inferior a cepa selvagem, respectivamente. Pode-se concluir então que a deleção do operon pntAB foi uma estratégia que teve efeito positivo na produção de $\mathrm{P} 3 \mathrm{HB}$ em $E$. coli recombinante em frasco agitado, principalmente em meio mineral sem suplementação de $\mathrm{NaCl}$, mas que deleção de um dos genes transidrogenase não foi uma estratégia eficiente para melhorar a produtividade de $\mathrm{P} 3 \mathrm{HB}$ em E. coli recombinante, nas condições testadas em biorreator. Para trabalhos futuros envolvendo modificação nos genes transidrogenase, uma possibilidade é seguir como exemplo o trabalho de Jan et al. de 2013, e testar também cepas com superexpressão do operon pntAB ou gene $u d h A$, super-expressão de ambos, deleção de ambos, e ainda cepas com super-expressão de um gene e deleção do outro, mas com foco no efeito na produção de poli-3-hidroxibutirato, de forma a permitir identificar qual modificação dos genes transidrogenase, dentre todas as possibilidades, será a mais benéfica na produção de P3HB. 


\section{REFERÊNCIAS}

ABDULKARIM, S. M.; FATIMAH, A. B.; ANDERSON, J. G. Effect of salt concentrations on the growth of heat-stressed and unstressed Escherichia coli. Journal of Food, Agriculture and Environment, v. 7, n. 3-4, p. 51-54, 2009.

AHMAD, S.; GLAVAS, N. A.; BRAGG, P. D. Subunit interactions involved in the assembly of pyridine nucleotide transhydrogenase in the membranes of Escherichia coli. The Journal of biological chemistry, v. 267, n. 10, p. 7007-12, 5 abr. 1992.

AHN, W. S.; PARK, S. J.; LEE, S. Y. Production of poly ( 3-hydroxybutyrate ) from whey by cell recycle fed-batch culture of recombinant Escherichia coli.

Biotechnology Letters, v. 23, n. 12, p. 235-240, 2001.

AKINTERINWA, O.; CIRINO, P. C. Anaerobic obligatory xylitol production in Escherichia coli strains devoid of native fermentation pathways. Applied and Environmental Microbiology, v. 77, n. 2, p. 706-709, 2011.

ALDOR, I. S.; KEASLING, J. D. Process design for microbial plastic factories: metabolic engineering of polyhydroxyalkanoates. Current Opinion in Biotechnology, v. 14, n. 5, p. 475-483, out. 2003.

ALI, I.; JAMIL, N. Polyhydroxyalkanoates: Current applications in the medical field. Frontiers in Biology, v. 11, n. 1, p. 19-27, fev. $2016 a$.

ALI, I.; JAMIL, N. Polyhydroxyalkanoates: Current applications in the medical field. Frontiers in Biology, v. 11, n. 1, p. 19-27, fev. 2016b.

AMOS, J. Poluição ameaça tornar a Terra um "Planeta de plástico". Disponível em: <https://www.bbc.com/portuguese/geral-40677873>. Acesso em: 13 jan. 2019.

ANDERLUND, M. et al. Expression of the Escherichia coli pntA and pntB genes, encoding nicotinamide nucleotide transhydrogenase, in Saccharomyces cerevisiae and its effect on product formation during anaerobic glucose fermentation. Applied and environmental microbiology, v. 65, n. 6, p. 2333-40, jun. 1999.

ANDERSON, A. J.; DAWES, E. A. Occurrence, metabolism, metabolic role, and industrial uses of bacterial polyhydroxyalkanoates. Microbiological reviews, v. 54, n. 4, p. 450-472, 1990.

ANDREESSEN, B.; TAYLOR, N.; STEINBÜCHEL, A. Poly(3-hydroxypropionate): A promising alternative to fossil fuel-based materials. Applied and Environmental 
Microbiology, v. 80, n. 21, p. 6574-6582, 2014.

ARENSE, P. et al. Metabolic adaptation of Escherichia coli to long-term exposure to salt stress. Process Biochemistry, v. 45, n. 9, p. 1459-1467, set. 2010.

ARIFIN, Y. et al. Deletion of $c s c R$ in Escherichia coli W improves growth and poly-3hydroxybutyrate $(\mathrm{PHB})$ production from sucrose in fed batch culture. Journal of Biotechnology, v. 156, n. 4, p. 275-278, dez. 2011.

BARBOSA, H. R.; GOMEZ, J. G. C.; TORRES, B. B. Microbiologia Básica Bacteriologia. 2. ed. São Paulo: Editora Atheneu LTDA., 2018. cap. 3, p. 60-129.

BASTIAN, S. et al. Engineered ketol-acid reductoisomerase and alcohol dehydrogenase enable anaerobic 2-methylpropan-1-ol production at theoretical yield in Escherichia coli. Metabolic Engineering, v. 13, n. 3, p. 345-352, 2011.

BHATIA, S. K. et al. Starch based polyhydroxybutyrate production in engineered Escherichia coli. Bioprocess and Biosystems Engineering, v. 38, n. 8, p. 14791484, 28 ago. 2015.

BOCANEGRA, J. K. Produção de Poli-hidroxialcanoatos por Linhagens

Recombinantes de Escherichia coli. 2012. 203 f. Tese (Doutorado em Biotecnologia) - Faculdade de Biotecnologia, Universidade de São Paulo, São Paulo, 2012.

BOONSTRA, B. et al. The udhA Gene of Escherichia coli Encodes a Soluble Pyridine Nucleotide Transhydrogenase. v. 181, n. 3, p. 1030-1034, 1999.

BRADFORD, A. What is a Polymer? Disponível em:

<https://www.livescience.com/60682-polymers.html>. Acesso em: 14 jan. 2018.

BRAGG, P. D. Site-directed mutagenesis of the proton-pumping pyridine nucleotide transhydrogenase of Escherichia coli. Biochimica et Biophysica Acta (BBA) Bioenergetics, v. 1365, n. 1-2, p. 98-104, jun. 1998.

BUCCI, D. Z. Avaliação de embalagens de PHB (Poli (Ácido 3 - Hidroxibutírico)) para alimentos. 2003. 166 f. Dissertação (Mestrado em Engenharia de Produção) Faculdade de Engenharia de Produção, Universidade Federal de Santa Catarina, Florianópolis, 2003.

CÁNOVAS, M. et al. Salt stress effects on the central and carnitine metabolisms of Escherichia coli. Biotechnology and Bioengineering, v. 96, n. 4, p. 722-737, 1 
mar. 2007.

CENTENO-LEIJA, S. et al. Improving poly-3-hydroxybutyrate production in Escherichia coli by combining the increase in the NADPH pool and acetyl-CoA availability. Antonie van Leeuwenhoek, v. 105, n. 4, p. 687-696, 6 abr. 2014.

CHEN, G.-Q. A microbial polyhydroxyalkanoates (PHA) based bio- and materials industry. Chemical Society Reviews, v. 38, n. 8, p. 2434, 2009.

CHIN, J. W. et al. Analysis of NADPH supply during xylitol production by engineered Escherichia coli. Biotechnology and Bioengineering, v. 102, n. 1, p. 209-220, 1 jan. 2009.

CHOI, J.; LEE, S. Y. Process analysis and economic evaluation for Poly(3hydroxybutyrate) production by fermentation. Bioprocess Engineering, v. 17, n. 6, p. 335, 1997.

CHOI, J.; LEE, S. Y. Factors affecting the economics of polyhydroxyalkanoate production by bacterial fermentation. Applied Microbiology and Biotechnology, $v$. 51, n. 1, p. 13-21, 27 jan. 1999.

CHOU, H. H.; MARX, C. J.; SAUER, U. Transhydrogenase Promotes the Robustness and Evolvability of E. coli Deficient in NADPH Production. PLoS Genetics, v. 11, n. 2, p. 1-26, 2015.

Cinco gráficos que explicam como a poluição por plástico ameaça a vida na Terra. Disponível em: <https://www.bbc.com/portuguese/geral-42308171>. Acesso em: 13 jan. 2018.

FRY, N. K. et al. Direct amplification and sequencing of the 16S ribosomal DNA of an intracellular Legionella species recovered by amoebal enrichment from the sputum of a patient with pneumonia. FEMS Microbiol Lett, v. 67, n. 2, p. 165-168, 1991.

FU, X.-Z. et al. Development of Halomonas TD01 as a host for open production of chemicals. Metabolic Engineering, v. 23, p. 78-91, maio 2014.

GANESH, M. et al. Effective production of low crystallinity Poly(3-hydroxybutyrate) by recombinant $E$. coli strain JM109 using crude glycerol as sole carbon source.

Bioresource Technology, v. 192, p. 677-681, 2015. 
f. Dissertação (Metrado em Engenharia de Alimentos) - Faculdade de Engenharia de Alimentos, Universidade Federal de Santa Catarina, Florianópolis, 2005.

HAVERKORN VAN RIJSEWIJK, B. R. B. et al. Distinct transcriptional regulation of the two Escherichia coli transhydrogenases PntAB and UdhA. Microbiology, v. 162, n. 9, p. 1672-1679, 1 set. 2016.

HOEK, J. B.; RYDSTROM, J. Physiological roles of nicotinamide nucleotide transhydrogenase. Biochemical Journal, v. 254, n. 1, p. 1-10, 1988.

HOLM, A. K. et al. Metabolic and transcriptional response to cofactor perturbations in Escherichia coli. Journal of Biological Chemistry, v. 285, n. 23, p. 17498-17506, 2010.

HOLMES, P. A. Applications of PHB - a microbially produced biodegradable thermoplastic. Physics in Technology, v. 16, n. 1, p. 32-36, jan. 1985.

HONG, P. H. et al. Effect of NADH kinase on poly-3-hydroxybutyrate production by recombinant Escherichia coli. Journal of Bioscience and Bioengineering, v. 122, n. 6, p. 685-688, 2016.

HOUSSIN, C. et al. Effect of osmotic pressure on membrane energy-linked functions in Escherichia coli. Biochimica et Biophysica Acta (BBA) - Bioenergetics, v. 1056, n. 1, p. 76-84, jan. 1991.

JAN, J. et al. Metabolic engineering and transhydrogenase effects on NADPH availability in Escherichia coli. Biotechnology Progress, v. 29, n. 5, p. 1124-1130, set. 2013.

JARI, M. et al. Cloning and Expression of Poly 3-Hydroxybutyrate Operon Into Escherichia coli. Jundishapur Journal of Microbiology, v. 8, n. 2, p. 3-6, 20 fev. 2015.

KABUS, A. et al. Expression of the Escherichia coli pntAB genes encoding a membrane-bound transhydrogenase in Corynebacterium glutamicum improves Llysine formation. Applied Microbiology and Biotechnology, v. 75, n. 1, p. 47-53, 2007.

KESHAVARZ, T.; ROY, I. Polyhydroxyalkanoates: bioplastics with a green agenda. Current Opinion in Microbiology, v. 13, n. 3, p. 321-326, jun. 2010.

LEE, S. H. et al. Metabolic engineering of Escherichia coli for enhanced biosynthesis 
of poly(3-hydroxybutyrate) based on proteome analysis. Biotechnology Letters, v. 35 , n. 10 , p. $1631-1637,7$ out. $2013 a$.

LEE, S. Y. Bacterial Polyhydroxyalkanoates. Biotechnology and bioengineering, v. 49, p. 1-14, 1996.

LEE, W.-H. et al. Engineering of NADPH regenerators in Escherichia coli for enhanced biotransformation. Applied Microbiology and Biotechnology, v. 97, n. 7, p. 2761-2772, 19 abr. 2013b.

LIN, Z. et al. Metabolic engineering of Escherichia coli for poly(3-hydroxybutyrate) production via threonine bypass. Microbial Cell Factories, v. 14, n. 1, p. 185, 20 dez. 2015.

LONG, C. P. et al. Dissecting the genetic and metabolic mechanisms of adaptation to the knockout of a major metabolic enzyme in Escherichia coli. Proceedings of the National Academy of Sciences, v. 115, n. 1, p. 222-227, 2 jan. 2018.

MENG, D. C. et al. Production of poly(3-hydroxypropionate) and poly(3hydroxybutyrate-co-3-hydroxypropionate) from glucose by engineering Escherichia coli. Metabolic Engineering, v. 29, p. 189-195, 2015.

MEULLER, J. et al. Properties of a proton-translocating nicotinamide nucleotide transhydrogenase from Escherichia coli with $\alpha$ and $\beta$ subunits linked through fused transmembrane helices. Biochimica et Biophysica Acta (BBA) - Bioenergetics, v. 1506, n. 3, p. 163-171, nov. 2001.

NARANJO, J. M. et al. Valorization of glycerol through the production of biopolymers: The PHB case using Bacillus megaterium. Bioresource Technology, v. 133, p. 3844, abr. 2013.

NIGMATULLIN, R. et al. Polyhydroxyalkanoates, a family of natural polymers, and their applications in drug delivery. Journal of Chemical Technology and Biotechnology, v. 90, n. 7, p. 1209-1221, 2015.

OBRUCA, S. et al. Involvement of polyhydroxyalkanoates in stress resistance of microbial cells: Biotechnological consequences and applications. Biotechnology Advances, v. 36, n. 3, p. 856-870, maio 2018.

PARKER, L. We made plastic. We depend on it. Now we're drowning in it. Disponível em: <https://www.nationalgeographic.com/magazine/2018/06/plasticplanet-waste-pollution-trash-crisis/>. Acesso em: 13 jan. 2018. 
PASSANHA, P. et al. The use of $\mathrm{NaCl}$ addition for the improvement of polyhydroxyalkanoate production by Cupriavidus necator. Bioresource Technology, v. 163, p. 287-294, jul. 2014.

PHILIP, S.; KESHAVARZ, T.; ROY, I. Polyhydroxyalkanoates: biodegradable polymers with a range of applications. Journal of Chemical Technology \& Biotechnology, v. 82, n. 3, p. 233-247, mar. 2007.

PHITHAKROTCHANAKOON, C. et al. Production of Polyhydroxyalkanoates from Crude Glycerol Using Recombinant Escherichia coli. Journal of Polymers and the Environment, v. 23, n. 1, p. 38-44, 2015.

PONTRELLI, S. et al. Escherichia coli as a host for metabolic engineering. Metabolic Engineering, v. 50, n. February, p. 16-46, nov. 2018.

RAICHER, G. Análise Econômica da Produção de Polímeros Biodegradáveis no contexto de uma Biorefinaria a partir de cana-de-açúcar. 2011. 178 f. Tese (Doutorado em Biotecnologia) - Faculdade de Biotecnologia, Universidade de São Paulo, São Paulo, 2011.

RAMSAY, B.; LOMALIZA, K.; CHAVARIE, C.; DUBE, B.; BATAILLE, P.; RAMSAY, J. Production of Poly-( $\beta$-Hydroxybutyric-Co- $\beta$-Hydroxyvaleric) Acids. Appl. Environ. Microbiol, v. v. 56, p. 2093-2098, 1990.

RATHNASINGH, C. et al. Production of 3-hydroxypropionic acid via malonyl-CoA pathway using recombinant Escherichia coli strains. Journal of Biotechnology, v. 157, n. 4, p. 633-640, fev. 2012.

Real Time Price List. Disponível em:

$<$ https://plasticker.de/preise/pms_en.php?kat=Mahlgut\&aog=A\&show=ok\&make=ok> . Acesso em: 15 jan. 2019.

RIIS, V.; MAI, W. Gas chromatographic determination of poly- $\beta$-hydroxybutyric acid in microbial biomass after hydrochloric acid propanolysis. Journal of Chromatography A, v. 445, p. 285-289, jan. 1988.

SAMBROOK, J.; FRITSCH, E. F.; MANIATIS, T. Molecular cloning: a laboratory manual. 2rd ed. New York: Cold Spring Harbor Laboratory Press, 1989.

SANCHEZ, A. M. et al. Effect of Overexpression of a Soluble Pyridine Nucleotide Transhydrogenase (UdhA) on the Production of Poly(3-hydroxybutyrate) in Escherichia coli. Biotechnology Progress, v. 22, n. 2, p. 420-425, 7 abr. 2006. 
SAUER, U. et al. The Soluble and Membrane-bound Transhydrogenases UdhA and PntAB Have Divergent Functions in NADPH Metabolism of Escherichia coli. Journal of Biological Chemistry, v. 279, n. 8, p. 6613-6619, 20 fev. 2004.

SHABALA, L. et al. Ion transport and osmotic adjustment in Escherichia coli in response to ionic and non-ionic osmotica. Environmental Microbiology, v. 11, n. 1, p. 137-148, jan. 2009.

SHAH, P.; CHIU, F.-S.; LAN, J. C.-W. Aerobic utilization of crude glycerol by recombinant Escherichia coli for simultaneous production of poly 3-hydroxybutyrate and bioethanol. Journal of Bioscience and Bioengineering, v. 117, n. 3, p. 343350, mar. 2014.

SOMBRIO, B. R. Produção de poli(3-hidroxibutirato) por cupriavidus necator em processo descontínuo alimentado com pulso de glicerol. 2015. $95 \mathrm{f}$.

Dissertação (Mestrado em Engenharia de Processos) - Faculdade de Engenharia de Processos, Universidade da Região de Joinville - UNIVILLE, Joinville, 2015.

SRIRANGAN, K. et al. Engineering of Escherichia coli for direct and modulated biosynthesis of poly(3-hydroxybutyrate-co-3-hydroxyvalerate) copolymer using unrelated carbon sources. Scientific Reports, v. 6, n. 1, p. 36470, 7 dez. 2016.

STEINBÜCHEL, A. Diversity of bacterial polyhydroxyalkanoic acids. FEMS Microbiology Letters, v. 128, n. 3, p. 219-228, 15 maio 1995.

STEINBÜCHEL, A.; FÜCHTENBUSCH, B. Bacterial and other biological systems for polyester production. Trends in Biotechnology, v. 16, n. 10, p. 419-427, 1998.

SUDESH, K.; ABE, H.; DOI, Y. Synthesis, structure and properties of polyhydroxyalkanoates: biological polyesters. Progress in Polymer Science, v. 25, n. 10, p. 1503-1555, dez. 2000.

SUDESH, K.; IWATA, T. Sustainability of biobased and biodegradable plastics. Clean - Soil, Air, Water, v. 36, n. 5-6, p. 433-442, 2008.

VOORDOUW, G.; VIES, S. M.; THEMMEN, A. P. N. Why Are Two Different Types of Pyridine Nucleotide Transhydrogenase Found in Living Organisms? European Journal of Biochemistry, v. 131, n. 3, p. 527-533, abr. 1983.

WANG, Q. et al. Complete PHB mobilization in Escherichia coli enhances the stress tolerance: a potential biotechnological application. Microbial Cell Factories, v. 8, n. 1, p. 47, 2009. 
WANG, Q. et al. Engineering of Escherichia coli for the biosynthesis of poly(3hydroxybutyrate-co-3-hydroxyhexanoate) from glucose. Applied Microbiology and

Biotechnology, v. 99, n. 6, p. 2593-2602, 2015.

WANG, R.-Y. et al. Enhanced co-production of hydrogen and poly-(R)-3hydroxybutyrate by recombinant PHB producing $E$. coli over-expressing hydrogenase 3 and acetyl-CoA synthetase. Metabolic Engineering, v. 14, n. 5, p. 496-503, set. 2012.

WECKBECKER, A.; HUMMEL, W. Improved synthesis of chiral alcohols with Escherichia coli cells co-expressing pyridine nucleotide transhydrogenase, NADP+dependent alcohol dehydrogenase and NAD+-dependent formate dehydrogenase. Biotechnology Letters, v. 26, n. 22, p. 1739-1744, nov. 2004.

What is the problem with plastic? Disponível em: <https://www.bbc.co.uk/newsround/42810179>. Acesso em: 13 jan. 2018.

YANG, Y.-H. et al. Biosynthesis of poly(3-hydroxybutyrate-co-3-hydroxyvalerate) containing a predominant amount of 3-hydroxyvalerate by engineered Escherichia coli expressing propionate-CoA transferase. Journal of Applied Microbiology, v. 113, n. 4, p. 815-823, out. 2012.

ZHANG, J. et al. Enhanced production of poly-3-hydroxybutyrate by Escherichia coli over-expressing multiple copies of NAD kinase integrated in the host genome.

Biotechnology Letters, v. 37, n. 6, p. 1273-1278, 2015.

ZHANG, Y. et al. Engineering of Serine-Deamination pathway, Entner-Doudoroff pathway and pyruvate dehydrogenase complex to improve poly(3-hydroxybutyrate) production in Escherichia coli. Microbial Cell Factories, v. 13, n. 1, p. 172, 16 dez. 2014.

ZHAO, $\mathrm{H}$. et al. Physiologic roles of soluble pyridine nucleotide transhydrogenase in Escherichia coli as determined by homologous recombination. Annals of Microbiology, v. 58, n. 2, p. 275-280, jun. 2008.

$\mathrm{ZHAO}, \mathrm{H}$. et al. The soluble transhydrogenase UdhA affecting the glutamatedependent acid resistance system of Escherichia coli under acetate stress. Biology Open, v. 7, n. 9, 15 set. 2018.

ZHENG, Y. et al. Engineering Escherichia coli for poly-(3-hydroxybutyrate) production guided by genome-scale metabolic network analysis. Enzyme and Microbial Technology, v. 106, n. June, p. 60-66, nov. 2017. 


\section{APÊNDICE A - DADOS DOS EXPERIMENTOS EM FRASCO AGITADO}

Tabela A.1 - Concentração de glicose no cultivo em frasco agitado em meio mineral sem $\mathrm{NaCl}$

\begin{tabular}{|c|c|}
\hline Amostra & Concentração (g/L) \\
\hline WT A Oh & 10,31 \\
\hline WT B Oh & 10,19 \\
\hline$\Delta p n t A B$ A Oh & 9,02 \\
\hline$\triangle p n t A B$ B Oh & 8,93 \\
\hline$\triangle p n t A B \mathrm{C}$ Oh & 9,07 \\
\hline$\Delta u d h A$ A Oh & 18,57 \\
\hline$\Delta u d h A$ B Oh & 18,25 \\
\hline$\Delta u d h A C$ Oh & 18,29 \\
\hline WT A 24h & 6,58 \\
\hline WT B 24h & 5,60 \\
\hline$\Delta p n t A B$ A $24 \mathrm{~h}$ & 5,51 \\
\hline$\Delta p n t A B$ B $24 \mathrm{~h}$ & 5,03 \\
\hline$\Delta p n t A B$ C $24 \mathrm{~h}$ & 5,44 \\
\hline$\Delta u d h A$ A $24 \mathrm{~h}$ & 15,40 \\
\hline$\Delta u d h A$ B $24 h$ & 15,42 \\
\hline$\Delta u d h A C 24 \mathrm{~h}$ & 15,26 \\
\hline WT A1 48h & 6,79 \\
\hline WT A2 48h & 4,02 \\
\hline WT B1 48h & 6,80 \\
\hline WT B2 48h & 5,32 \\
\hline$\Delta p n t A B$ A1 48h & 5,07 \\
\hline$\triangle p n t A B$ A2 48h & 4,25 \\
\hline$\Delta p n t A B$ B1 48h & 5,60 \\
\hline$\Delta p n t A B$ B2 48h & 3,09 \\
\hline
\end{tabular}

Fonte: Autoria própria (2019) 
Tabela A.2 - Dados de concentração de células, teor e concentração de P3HB do experimento em frasco agitado em meio mineral sem $\mathrm{NaCl}$

\begin{tabular}{|c|c|c|c|c|}
\hline Amostra & $\begin{array}{l}\text { Concentração } \\
\text { de células total } \\
(\mathrm{g} / \mathrm{L})\end{array}$ & $\begin{array}{c}\text { Teor de } \\
\text { P3HB } \\
\text { (\% massa) }\end{array}$ & $\begin{array}{c}\text { Concentração } \\
\text { de P3HB } \\
(g / L)\end{array}$ & $\begin{array}{c}\text { Concentração de } \\
\text { células residual } \\
(\mathrm{g} / \mathrm{L})\end{array}$ \\
\hline WT A 24h & 1,34 & vazou & vazou & vazou \\
\hline WT B 24h & 1,1 & 19,65 & 0,22 & 0,88 \\
\hline$\triangle p n t A B$ A 24h & 1,37 & 36,65 & 0,50 & 0,87 \\
\hline$\Delta p n t A B$ B 24h & 2,26 & 42,25 & 0,95 & 1,30 \\
\hline$\triangle p n t A B$ C 24h & 2,21 & 43,04 & 0,95 & 1,26 \\
\hline$\Delta u d h a$ A $24 h$ & 0,32 & vazou & vazou & vazou \\
\hline$\Delta u d h a$ B 24h & 0,54 & vazou & vazou & vazou \\
\hline$\Delta u d h a$ C $24 \mathrm{~h}$ & 0,62 & 36,00 & 0,22 & 0,40 \\
\hline WT A1 48h & 1,37 & 34,39 & 0,47 & 0,90 \\
\hline WT A2 48h & 1,29 & vazou & vazou & vazou \\
\hline WT B1 48h & 1,09 & 21,32 & 0,23 & 0,86 \\
\hline WT B2 48h & 1,02 & 21,88 & 0,22 & 0,80 \\
\hline$\triangle p n t A B$ A1 48h & 1,28 & 38,50 & 0,50 & 0,79 \\
\hline$\triangle p n t A B$ A2 48h & 1,33 & 37,38 & 0,50 & 0,83 \\
\hline$\triangle p n t A B$ B1 48h & 1,84 & 47,85 & 0,88 & 0,96 \\
\hline$\triangle p n t A B$ B2 48h & 1,76 & 44,22 & 0,78 & 0,98 \\
\hline$\triangle p n t A B$ C1 48h & 2,06 & 43,58 & 0,90 & 1,16 \\
\hline$\triangle p n t A B$ C2 48h & 1,7 & 44,62 & 0,76 & 0,94 \\
\hline$\Delta u d h a \mathrm{~A} 48 \mathrm{~h}$ & 0,42 & 52,46 & 0,22 & 0,20 \\
\hline$\Delta u d h a$ B 48h & 0,44 & 45,70 & 0,20 & 0,24 \\
\hline$\Delta u d h a$ C 48h & 0,42 & 54,52 & 0,23 & 0,19 \\
\hline
\end{tabular}

O termo "vazou", indica que houve vazamento da amostra durante o processo de propanólise, não permitindo assim, a quantificação

Fonte: Autoria própria (2019) 
Tabela A.3 - Concentração de glicose no cultivo em frasco agitado em meio mineral com NaCl

\begin{tabular}{|c|c|}
\hline Amostra & Concentração (g/L) \\
\hline WT A Oh & 17,92 \\
\hline WT B Oh & 18,74 \\
\hline WT C Oh & 17,84 \\
\hline$\Delta p n t A B$ A Oh & 18,88 \\
\hline$\triangle p n t A B$ B Oh & 15,54 \\
\hline$\triangle p n t A B \mathrm{C}$ Oh & 7,12 \\
\hline$\Delta u d h A$ A Oh & 18,90 \\
\hline$\Delta u d h A$ B Oh & 17,91 \\
\hline$\triangle u d h A C$ Oh & 18,85 \\
\hline WT A 24h & 10,19 \\
\hline WT B 24h & 7,13 \\
\hline WT C $24 \mathrm{~h}$ & 10,03 \\
\hline$\triangle p n t A B$ A $24 \mathrm{~h}$ & 11,51 \\
\hline$\Delta p n t A B$ B $24 \mathrm{~h}$ & 11,75 \\
\hline$\triangle p n t A B$ C $24 \mathrm{~h}$ & 14,76 \\
\hline$\Delta u d h A$ A $24 \mathrm{~h}$ & 15,35 \\
\hline$\Delta u d h A$ B $24 \mathrm{~h}$ & 14,49 \\
\hline$\Delta u d h A C 24 \mathrm{~h}$ & 15,31 \\
\hline WT A 48h & 9,48 \\
\hline WT B 48h & 5,60 \\
\hline WT C 48h & 9,34 \\
\hline$\Delta p n t A B$ A $48 \mathrm{~h}$ & 10,91 \\
\hline$\Delta p n t A B$ B $48 \mathrm{~h}$ & 11,26 \\
\hline$\triangle p n t A B C 48 \mathrm{~h}$ & 14,47 \\
\hline$\Delta u d h A$ A 48h & 15,27 \\
\hline$\Delta u d h A$ B $48 \mathrm{~h}$ & 14,24 \\
\hline$\Delta u d h A$ C 48h & 15,25 \\
\hline
\end{tabular}

Fonte: Autoria própria (2019) 
Tabela A.4 - Dados de concentração de células e acumulo e concentração de P3HB do experimento em frasco agitado em meio mineral com $\mathrm{NaCl}$

\begin{tabular}{|c|c|c|c|c|}
\hline Amostra & $\begin{array}{c}\text { Concentração } \\
\text { de células total } \\
(\mathrm{g} / \mathrm{L})\end{array}$ & $\begin{array}{c}\text { Acumulo } \\
\text { de P3HB } \\
(\% \text { massa) }\end{array}$ & $\begin{array}{c}\text { Concentração } \\
\text { de P3HB } \\
\text { (g/L) }\end{array}$ & $\begin{array}{c}\text { Concentração de } \\
\text { células residual } \\
(\mathrm{g} / \mathrm{L})\end{array}$ \\
\hline WT LB & 1,44 & 0,31 & 0 & 1,44 \\
\hline$\triangle p n t A B$ LB & 1,27 & 1,02 & 0,01 & 1,26 \\
\hline$\Delta u d h A$ LB & 1,18 & 0,81 & 0,01 & 1,17 \\
\hline WT A 24h & 1,98 & 28,75 & 0,57 & 1,41 \\
\hline WT B 24h & 3,20 & 47,82 & 1,53 & 1,67 \\
\hline WT C 24h & 2,24 & 33,72 & 0,76 & 1,48 \\
\hline$\Delta p n t A B$ A $24 \mathrm{~h}$ & 1,48 & 21,08 & 0,31 & 1,17 \\
\hline$\Delta p n t A B$ B $24 \mathrm{~h}$ & 1,38 & 15,12 & 0,21 & 1,17 \\
\hline$\triangle p n t A B$ C $24 \mathrm{~h}$ & 1,62 & 19,91 & 0,32 & 1,30 \\
\hline$\Delta u d h A$ A $24 h$ & 0,40 & vazou & vazou & vazou \\
\hline$\Delta u d h A$ B $24 h$ & 0,52 & 38,18 & 0,20 & 0,32 \\
\hline$\Delta u d h A C$ 24h & 0,54 & 34,17 & 0,18 & 0,36 \\
\hline WT A 48h & 1,98 & 25,38 & 0,50 & 1,48 \\
\hline WT B 48h & 3,04 & 46,73 & 1,42 & 1,62 \\
\hline WT C 48h & 2,02 & 35,97 & 0,73 & 1,29 \\
\hline$\Delta p n t A B$ A 48h & 1,38 & 18,81 & 0,26 & 1,12 \\
\hline$\Delta p n t A B$ B 48h & 1,30 & 14,96 & 0,19 & 1,11 \\
\hline$\triangle p n t A B$ C 48h & 1,36 & 24,91 & 0,34 & 1,02 \\
\hline$\Delta u d h A$ A 48h & 0,70 & 51,13 & 0,36 & 0,34 \\
\hline$\Delta u d h A$ B 48h & 0,52 & 48,35 & 0,25 & 0,27 \\
\hline$\Delta u d h A$ C 48h & 0,64 & 41,61 & 0,27 & 0,37 \\
\hline
\end{tabular}

O termo "vazou", indica que houve vazamento da amostra durante o processo de propanólise, não permitindo assim, a quantificação

Fonte: Autoria própria (2019) 


\section{APÊNDICE B - DADOS DOS EXPERIMENTOS EM BIORREATOR}

Tabela B.1 - Dados de concentração de células, teor e concentração de P3HB do experimento em biorreator com cepa selvagem em meio mineral com $\mathrm{NaCl}$

\begin{tabular}{ccccc}
\hline Amostra & $\begin{array}{c}\text { Tempo } \\
(\mathrm{h})\end{array}$ & $\begin{array}{c}\text { Concentração } \\
\text { de células total } \\
(\mathrm{g} / \mathrm{L})\end{array}$ & $\begin{array}{c}\text { Teor de } \\
\text { P3HB } \\
(\% \text { massa })\end{array}$ & $\begin{array}{c}\text { Concentração de } \\
\text { glicose } \\
(\mathrm{g} / \mathrm{L})\end{array}$ \\
\hline 1 & & & & \\
\hline 2 & 0 & 0,07 & 0,00 & 16,61 \\
3 & 1,5 & 0,09 & 4,41 & 16,49 \\
4 & 3 & 0,06 & 9,05 & 16,28 \\
5 & 4,5 & 0,12 & 6,67 & 15,96 \\
6 & 6 & 0,14 & 5,44 & 15,36 \\
7 & 7,5 & 0,25 & 4,52 & 14,20 \\
8 & 9 & 0,62 & 4,71 & 11,21 \\
9 & 10,5 & 0,85 & 4,31 & 9,14 \\
10 & 12 & 0,90 & vazou & 7,07 \\
11 & 13,5 & 0,83 & 5,84 & 5,63 \\
12 & 15 & 0,85 & 7,31 & 4,45 \\
13 & 16,5 & 0,89 & 7,38 & 2,82 \\
14 & 18 & 0,82 & 9,62 & 1,85 \\
15 & 19,5 & 0,83 & 9,90 & 1,12 \\
16 & 21 & 1,02 & 11,99 & 1,06 \\
17 & 22,5 & 0,83 & 11,63 & 1,19 \\
18 & 24 & 0,84 & 34,16 & 1,03 \\
19 & 25,5 & 0,76 & 13,77 & 2,43 \\
20 & 27,5 & 0,93 & 14,76 & 2,63 \\
21 & 29,5 & 0,76 & 16,09 & 2,18 \\
22 & 31,5 & 1,02 & 15,83 & 7,95 \\
23 & 33,5 & 0,90 & 15,97 & 7,17 \\
24 & 35,5 & 0,89 & 15,10 & 13,36 \\
\hline
\end{tabular}

O termo "vazou", indica que houve vazamento da amostra durante o processo de propanólise, não permitindo assim, a quantificação

Fonte: Autoria própria (2019) 
Tabela B.2 - Dados de concentração de células, teor e concentração de P3HB do experimento em biorreator com cepa $\triangle p n t A B$ em meio mineral com $\mathrm{NaCl}$

\begin{tabular}{ccccc}
\hline Amostra & $\begin{array}{c}\text { Tempo } \\
(\mathrm{h})\end{array}$ & $\begin{array}{c}\text { Concentração } \\
\text { de células total } \\
(\mathrm{g} / \mathrm{L})\end{array}$ & $\begin{array}{c}\text { Teor de } \\
\text { P3HB } \\
(\% \text { massa })\end{array}$ & $\begin{array}{c}\text { Concentração de } \\
\text { glicose } \\
(\mathrm{g} / \mathrm{L})\end{array}$ \\
\hline 1 & & & & \\
\hline 2 & 0 & 0,04 & 0,00 & 16,41 \\
3 & 1,5 & 0,16 & 1,70 & 16,43 \\
4 & 3 & 0,14 & 2,26 & 16,53 \\
5 & 4,5 & 0,40 & 1,57 & 15,19 \\
6 & 6 & 0,42 & 2,11 & 13,41 \\
7 & 7,5 & 0,63 & 1,71 & 10,25 \\
8 & 9 & 0,74 & 1,74 & 7,45 \\
9 & 10,5 & 0,76 & 2,43 & 6,62 \\
10 & 12 & perdido & perdido & 5,49 \\
11 & 13,5 & 0,73 & 4,36 & 4,39 \\
12 & 15 & 0,35 & vazou & 4,10 \\
13 & 16,5 & 0,84 & 6,54 & 3,37 \\
14 & 18 & 0,76 & 6,57 & 2,88 \\
15 & 19,5 & 0,83 & 3,62 & 2,36 \\
16 & 21 & 0,94 & 8,14 & 1,77 \\
17 & 22,5 & 0,73 & 8,16 & 1,21 \\
18 & 24 & 0,84 & 7,89 & 0,52 \\
19 & 25,5 & 0,53 & 10,66 & 3,34 \\
20 & 27,5 & 0,56 & vazou & 2,34 \\
21 & 29,5 & 0,98 & 10,25 & 1,79 \\
22 & 31,5 & 0,80 & 12,71 & 5,09 \\
23 & 33,5 & 0,88 & 12,84 & 4,71 \\
24 & 35,5 & 0,71 & 13,61 & 4,35 \\
& 37,5 & 0,87 & 14,82 & 11,05 \\
\hline
\end{tabular}

O termo "vazou", indica que houve vazamento da amostra durante o processo de propanólise, e o termo "perdido" indica um ponto que não foi propriamente amostrado, não permitindo assim, a quantificação

Fonte: Autoria própria (2019) 
Tabela B.3 - Dados de concentração de células, teor e concentração de P3HB do experimento em biorreator com cepa $\triangle u d h A$ em meio mineral com $\mathrm{NaCl}$

\begin{tabular}{ccccc}
\hline Amostra & $\begin{array}{c}\text { Tempo } \\
(\mathrm{h})\end{array}$ & $\begin{array}{c}\text { Concentração } \\
\text { de células total } \\
(\mathrm{g} / \mathrm{L})\end{array}$ & $\begin{array}{c}\text { Teor de } \\
\text { P3HB } \\
(\% \text { massa })\end{array}$ & $\begin{array}{c}\text { Concentração de } \\
\text { glicose } \\
(\mathrm{g} / \mathrm{L})\end{array}$ \\
\hline 1 & & & & \\
2 & 0 & 0,01 & 60,20 & 15,49 \\
3 & 1,5 & 0,07 & 11,29 & 14,81 \\
4 & 3 & 0,05 & 12,46 & 15,42 \\
5 & 4,5 & 0,01 & 51,83 & 16,54 \\
6 & 6 & 0,07 & 8,21 & 13,92 \\
7 & 7,5 & 0,02 & 23,53 & 15,39 \\
8 & 9 & 0,02 & 26,61 & 15,59 \\
9 & 10,5 & 0,11 & 7,79 & 14,91 \\
10 & 12 & 0,25 & 3,01 & 17,21 \\
11 & 13,5 & 0,43 & 1,75 & 15,75 \\
12 & 15 & 1,00 & 0,71 & 12,23 \\
13 & 16,5 & 1,07 & 0,88 & 10,40 \\
14 & 18 & 1,09 & 1,00 & - \\
15 & 19,5 & 1,19 & 1,22 & 8,99 \\
16 & 21 & 1,10 & 1,68 & 8,50 \\
17 & 22,5 & 1,10 & 1,39 & 12,98 \\
18 & 24 & 1,07 & vazou & 13,02 \\
19 & 26 & 1,11 & 2,02 & 12,46 \\
20 & 28 & 1,14 & 2,10 & 12,12 \\
21 & 30 & 1,12 & 2,24 & 11,08 \\
22 & 42,5 & 1,02 & 3,72 & 11,64 \\
23 & 43 & 1,10 & vazou & 7,04 \\
24 & 44 & 1,11 & 4,14 & 11,88 \\
& 45 & 1,04 & 4,06 & 11,92 \\
\hline
\end{tabular}

O termo "vazou", indica que houve vazamento da amostra durante o processo de propanólise, não permitindo assim, a quantificação

Fonte: Autoria própria (2019) 
Figura B.1 - Gráficos para determinação do fator de conversão dos experimentos em biorreator

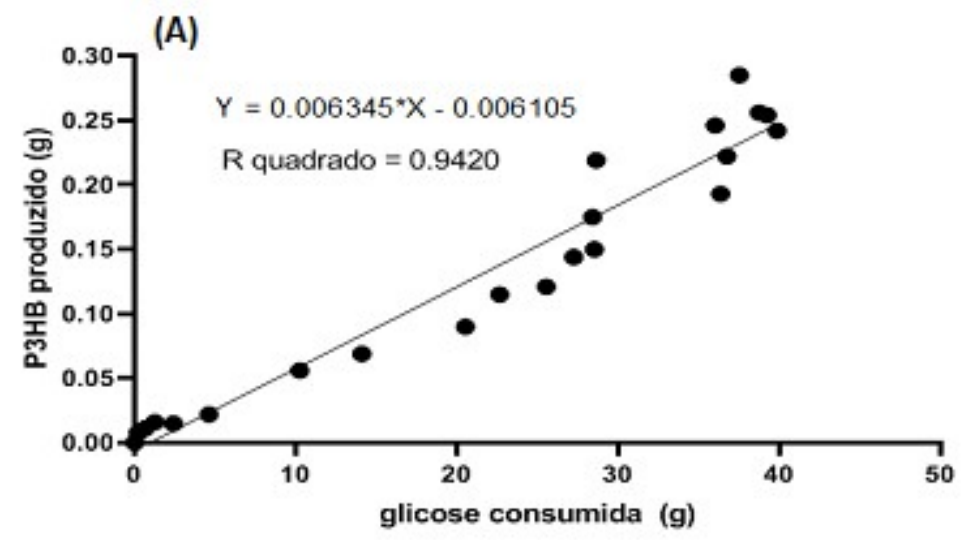

(B)

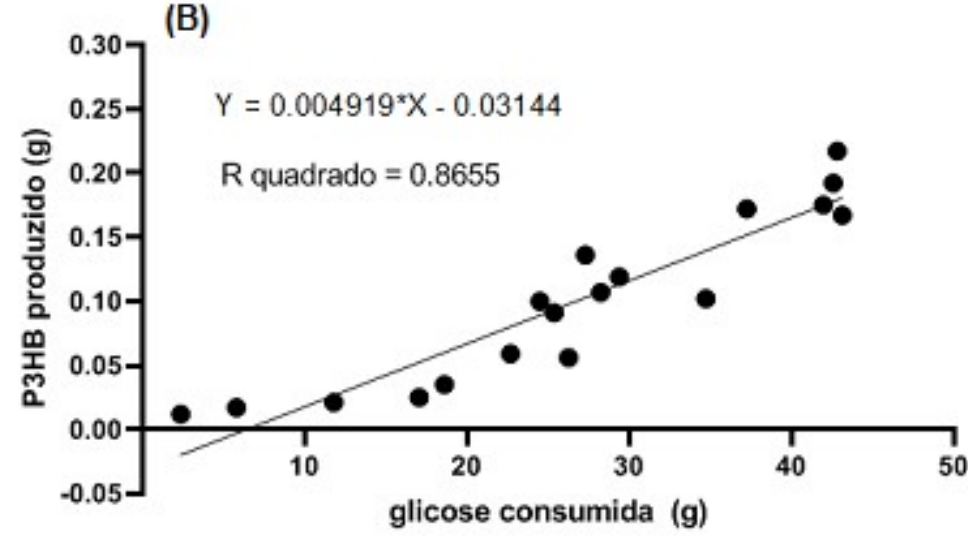

(C)

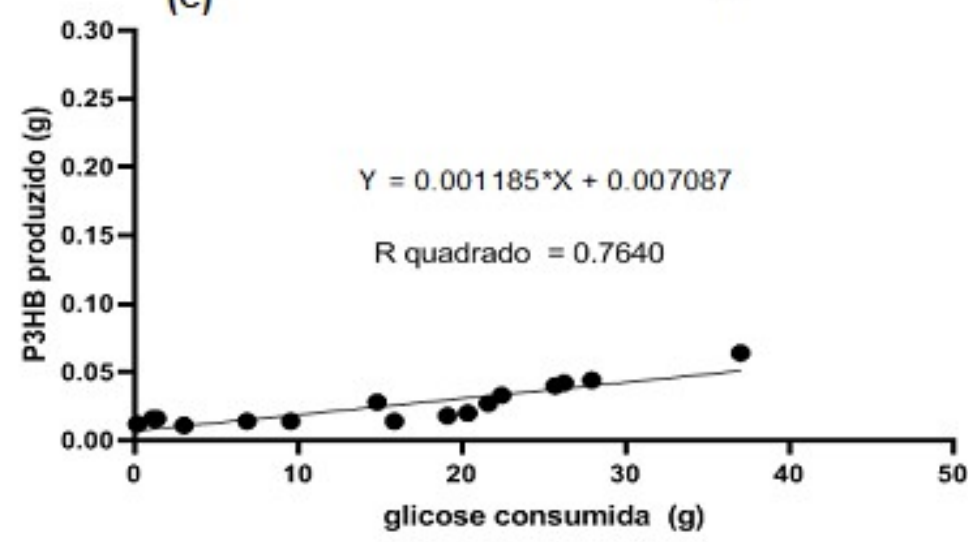

Razão entre P3HB produzido e glicose consumida para a cepa "selvagem" (A), e as mutantes $\triangle p n t A B(B)$ e $\triangle u d h A(C)$

Fonte: Autoria própria (2019) 


\section{APÊNDICE C - PARÂMETROS MONITORADOS E CONCENTRAÇÃO DE OUTROS METABOLITOS FORMADOS NOS EXPERIMENTOS EM BIORREATOR}

Figura C.1 - Porcentagem de oxigênio dissolvido ao longo do cultivo para as cepas selvagem, $\triangle p h t A B$ e $\triangle u d h A$ em meio com $\mathrm{NaCl}$
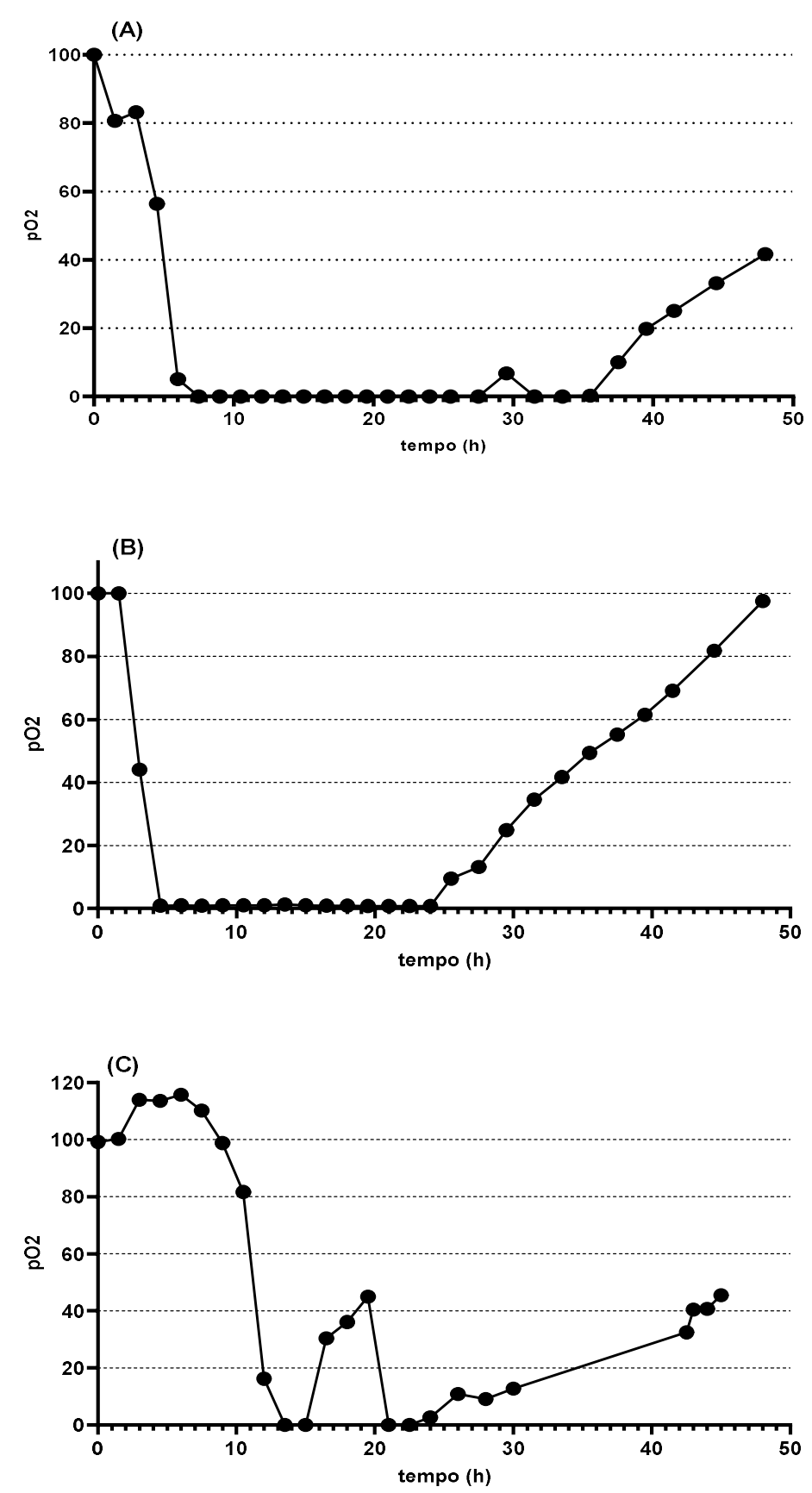

Porcentagem de oxigênio dissolvido no meio para a cepa "selvagem" $(A)$, e as mutantes $\triangle p n t A B(\mathrm{~B})$ e $\triangle u d h A(\mathrm{C})$

Fonte: Autoria própria (2019) 
Figura C.2 - pH ao longo do cultivo para as cepas selvagem, $\triangle p h t A B$ e $\triangle u d h A$ em meio com $\mathrm{NaCl}$
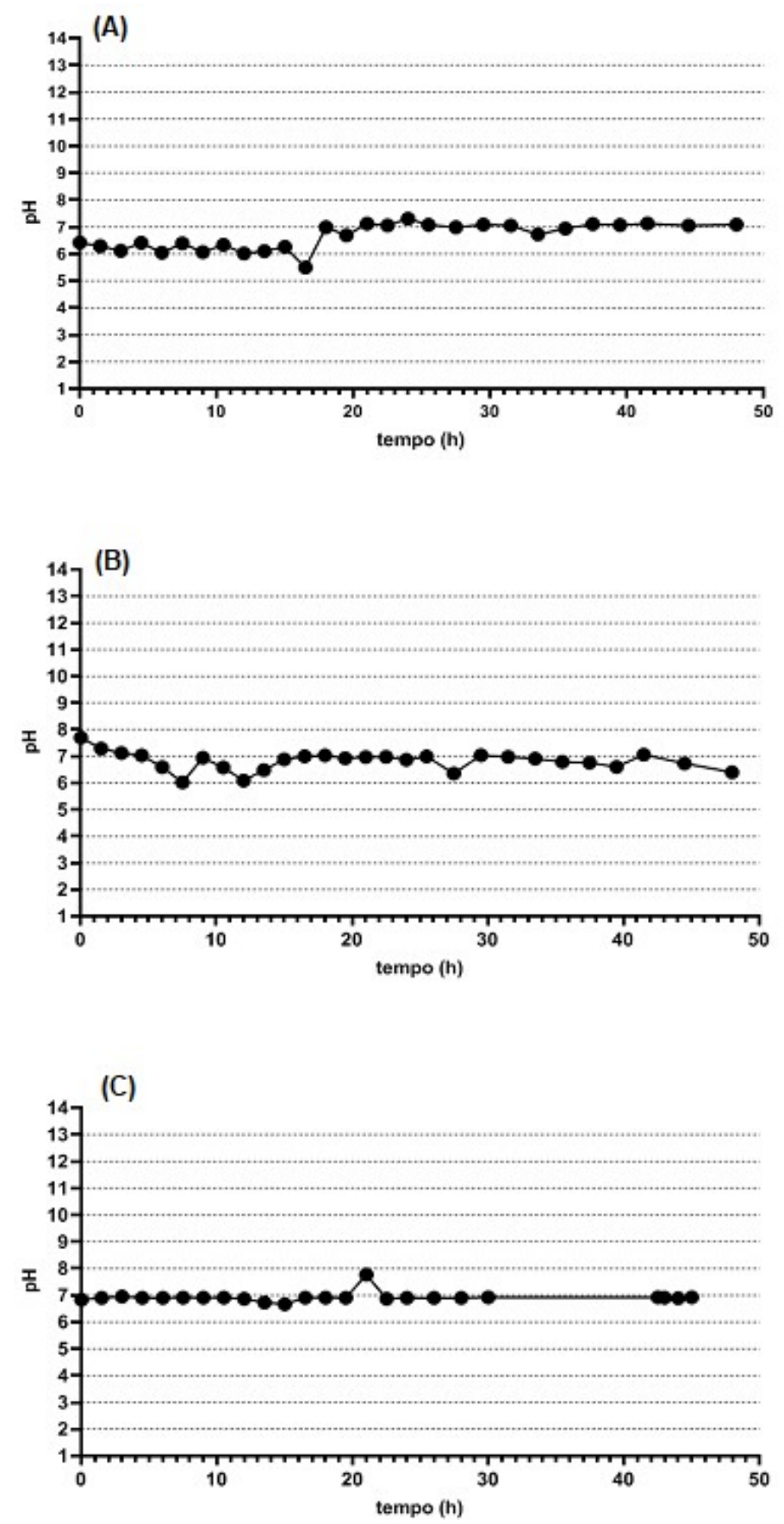

$\mathrm{pH}$ no meio para a cepa "selvagem" $(\mathrm{A})$, e as mutantes $\triangle p n t A B(B)$ e $\triangle u d h A(C)$

Fonte: Autoria própria (2019) 